\title{
Photovoltaicself-consumption in buildings: A review
}

\author{
Rasmus Luthander, Joakim Widén, Daniel Nilsson and Jenny Palm
}

\section{Linköping University Post Print}

\section{Tweet}

N.B.: When citing this work, cite the original article.

Original Publication:

Rasmus Luthander, Joakim Widén, Daniel Nilsson and Jenny Palm, Photovoltaicselfconsumption in buildings: A review, 2015, Applied Energy, (142), 80-94.

http://dx.doi.org/10.1016/j.apenergy.2014.12.028

Copyright: Elsevier

http://www.elsevier.com/

Postprint available at: Linköping University Electronic Press

http://urn.kb.se/resolve?urn=urn:nbn:se:liu:diva-113676 


\section{Photovoltaic self-consumption in buildings: A review}

Rasmus Luthander ${ }^{\mathrm{a}, *}$, Joakim Widén ${ }^{\mathrm{a}}$, Daniel Nilsson ${ }^{\mathrm{b}}$, Jenny Palm ${ }^{\mathrm{b}}$

${ }^{a}$ Built Environment Energy Systems Group (BEESG), Division of Solid State Physics, Department of Engineering Sciences, Uppsala University, P.O. Box 534, SE-751 21 Uppsala, Sweden.

${ }^{b}$ Linköping University, Department of Thematic Studies, Technology and Social Change, SE-581 83 Linköping, Sweden

* Corresponding author. Tel. +46184716215.

E-mail address: rasmus.luthander@angstrom.uu.se

Keywords: Photovoltaics; Self-consumption; Household electricity; Energy storage; Load shifting; Demand side management

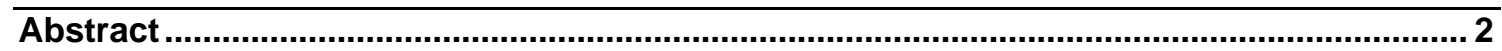

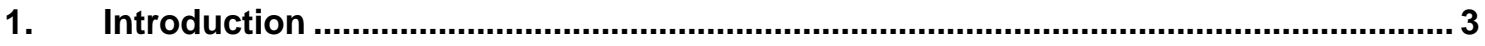

1.1 Brief overview of self-consumption policies and technologies ............................. 3

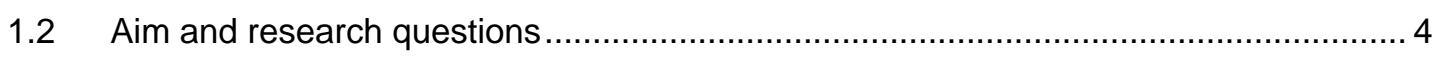

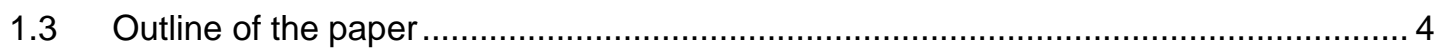

2. Self-consumption definition and metrics …...................................................... 5

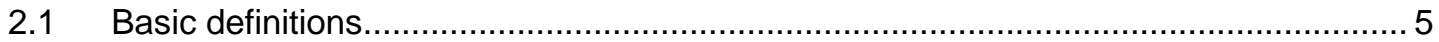

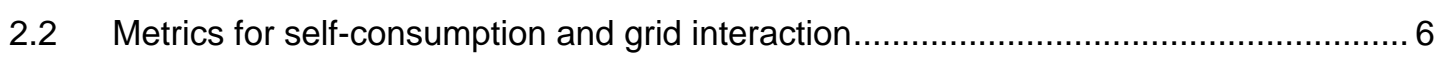

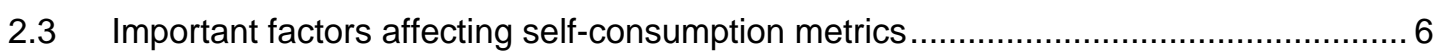

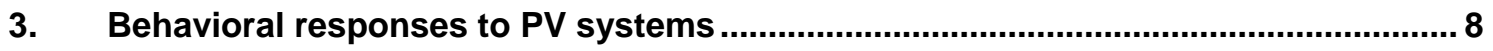

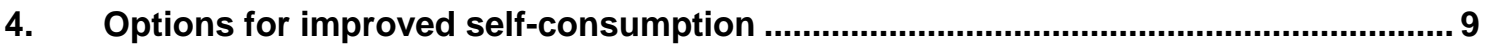

4.1 Demand side management (DSM) ……….................................................... 9

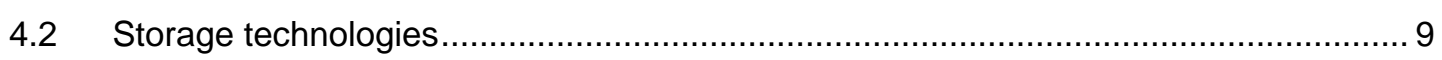

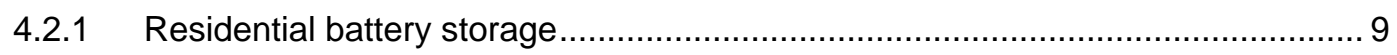

4.2.2 Other storage technologies ...................................................................... 10

5. Improved self-consumption ............................................................................... 11

6. Discussion and suggestions for further research............................................... 12

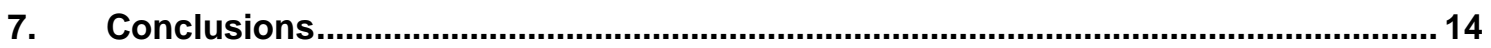

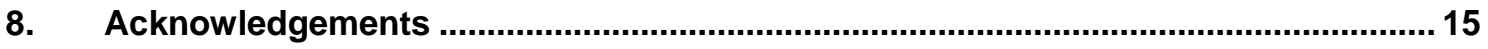

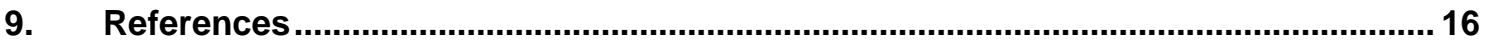




\section{Abstract}

The interest in self-consumption of PV electricity from grid-connected residential systems is increasing among PV system owners and in the scientific community. Self-consumption can be defined as the share of the total PV production directly consumed by the PV system owner. With decreased subsidies for PV electricity in several countries, increased self-consumption could raise the profit of PV systems and lower the stress on the electricity distribution grid. This review paper summarizes existing research on PV selfconsumption and options to improve it. Two options for increased self-consumption are included, namely energy storage and load management, also called demand side management (DSM). Most of the papers examine PV-battery systems, sometimes combined with DSM. The results show that it is possible to increase the relative self-consumption by 13 to 24 percentage points with a battery storage capacity of 0.5 to $1 \mathrm{kWh}$ per installed $\mathrm{kW}$ PV power and between 2 and 15 percentage points with DSM, both compared to the original rate of self-consumption. The total number of papers is however rather limited and further research and more comparative studies are needed to give a comprehensive view of the technologies and their potential. Behavioral responses to PV self-consumption and the impact on the distribution grid also need to be further studied. 


\section{Introduction}

In recent years, the installed photovoltaic (PV) capacity in the world has rapidly increased. In 2013, PV capacity of more than $37 \mathrm{GW}$ has been installed worldwide, adding up to a cumulative capacity of approximately $137 \mathrm{GW}$ [1]. While the European share of the world PV market has declined from more than 70 percent in 2011 to 28 percent in 2013, Asia now makes up the largest share of new PV installations [1]. The growth of the PV market has led to a significant price drop of new installations, with an average PV system price decline of 6 to 7 percent per year since 1998 [2]. PV modules have faced the largest price drop in the last years and the global module price index is now less than \$1 per W [2]. China is now the largest manufacturer of PV modules, with seven of the world's ten largest PV module suppliers [3]. The main reason to the Chinese dominance is the scale and supply-chain development [4].

The vast majority of all PV installations today are grid-connected [5]. Therefore, the PV production does not have to match the local consumption, in contrast to off-grid PV systems where the electricity production and storage have to match the consumption instantly as well as over a longer period of time. Traditionally, electricity is generated at large-scale power plants and distributed to the consumers via a network of high- and low-voltage transmission and distribution lines. Distributed generation, often intermittent such as small scale PV and micro-turbines, is often located closer to the consumers, resulting in a number of potential benefits such as reduced peak power consumption and increased power quality [6], [7]. There are however challenges needed to be solved to achieve a high penetration of intermittent electricity production in the electric power system, such as frequency regulation, the ability to rapidly start and ramp the remaining electric power generation and better match the consumption with the intermittent generation to avoid exceeding voltage limits [8-10]. The latter case can partly be achieved with increased self-consumption of the distributed generation. Self-consumption is in this paper defined as the PV production consumed directly by the producer, which often is the owner of the PV system.

\subsection{Brief overview of self-consumption policies and technologies}

To promote PV electricity in the power system, support policies have been introduced in several countries to compensate for the gap between the costs of PV production and the revenue from utilizing or selling the PV electricity $[11,12]$. However, the cost of self-produced PV electricity is nowadays lower than the retail price of electricity in some countries, which makes self-consumption profitable without subsidies [5]. There exist several different incentives for renewable energy such as PV, for example feed-in tariffs (FiT), quota and trading systems, portfolio standards, tax credits and pricing laws [13]. In 2012, FiT schemes contributed to the largest share of the market incentives, but self-consumption is becoming a more important motive force [5].

The billing period is also an important aspect. The traditional definition of self-consumption states that PV electricity is consumed instantaneously or within a 15 minutes time frame [5]. Instead, so-called net-metering can be used to set off PV production over a longer period of time against the consumption, which means that the production can be "stored" in the electric grid and thus increase the self-consumption as recorded on the meter or the bill [5,14]. If net metering is used on a yearly basis, surplus PV production during the summer months can be saved to the winter months with surplus consumption or vice versa.

Germany has, since 2000, a comprehensive act for encouraging renewable energy, the Renewable Energy Act (Erneuerbare-Energien-Gesetz) [15]. Until 2012, there was a special bonus for self-consumed electricity, but since the FiT fell below the retail price of electricity, self-consumption has become profitable even without the extra incentive and it has therefore disappeared [5,16]. China has also recently introduced a self-consumption subsidy and Japan has a slightly higher feed-in tariff for micro-producers with selfconsumption [5]. In the end of 2012, Italy also had a premium dedicated to self-consumption similar to the one in Germany, called V Conto Energia, whereas countries such as Denmark, the Netherlands, Belgium, Turkey and some US states have net-metering schemes [5,16,17].

There exist different technologies to increase PV self-consumption, where the two major ones are energy storage, mainly using batteries, and active load shifting, which is an important part of the concept demand side management (DSM) [18]. Depending on the revenue of selling PV generated electricity to and cost of buying electricity from the grid, increased self-consumption using these options or combinations of them can be profitable for owners of small-scale PV systems. 


\subsection{Aim and research questions}

The aim of this review paper is to give an overview of PV self-consumption in residential buildings and to summarize results from previous papers within the field. Similarities and differences between the studies are presented and discussed. Moreover, the review paper forms a basis and gives suggestions for further studies of self-consumption from PV systems. The following research questions will be examined in this paper:

- How can self-consumption for a residential PV system be defined?

- What is the spontaneous self-consumption increase in response to installing a PV system in a household?

- Which methods exist to increase the self-consumption for a residential PV system?

- How much can the self-consumption be increased according to previous studies?

- Which are the identified knowledge gaps in the literature and what should be focused on in further research?

\subsection{Outline of the paper}

The outline of the paper is as follows: Section 2 will give an introduction on self-consumption and how to define it. In Section 3, previous research results on 'spontaneous' self-consumption improvement or change in energy use due to increased awareness, etc. will be presented. The different alternatives of increasing the self-consumption from PV systems are discussed in Section 4 together with an overview of papers using the different methods. A comprehensive overview of papers presenting explicit results of how much the self-consumption can be increased with the different methods is included in Section 5. In Section 6, a discussion of the findings and suggestions for further research can be found, together with other important aspects of self-consumption. Finally, conclusions from the review are compiled in Section 7. 


\section{Self-consumption definition and metrics}

In this section, self-consumption is more formally defined and some relevant metric types are reviewed and discussed. An overview of the most important factors affecting the metrics and the interpretation of them is also included.

\subsection{Basic definitions}

Figure 1 shows a schematic outline of the power profiles of on-site PV generation and power consumption. The areas $\mathrm{A}$ and $\mathrm{B}$ are the total net electricity demand and generation, respectively. The overlapping part in area $\mathrm{C}$ is the PV power that is utilized directly within the building. This is sometimes referred to as the absolute self-consumption (as in [19]). What is most commonly meant by self-consumption, however, is the self-consumed part relative to the total production, which in the simplified nomenclature of Figure 1 would be:

$$
\text { Self-consumption }=\frac{C}{B+C}
$$

The self-consumed part relative to the total load is also a commonly used metric. As shown below, many denominations have been proposed for it, and there is no consensus on a common nomenclature. In the following we will refer to it as the self-sufficiency (as in [20]) both because this clearly expresses what the metric shows - the degree to which the on-site generation is sufficient to fill the energy needs of the building - and because of its linguistic symmetry to the word self-consumption:

$$
\text { Self-sufficiency }=\frac{C}{A+C}
$$

To define self-consumption more formally, we denote the instantaneous building power consumption $L(t)$ and the instantaneous on-site PV power generation $P(t)$. The power generation utilized on-site is limited by whichever of the load and the generation profiles is the smallest, which can be expressed as:

$$
M(t)=\min \{L(t), P(t)\}
$$

where $M(t)$ is the instantaneously overlapping part of the generation and load profiles. In the case of energy storage (battery or heat storage) in the building this can be extended to

$$
M(t)=\min \{L(t), P(t)+S(t)\}
$$

where $S(t)$ is the power to and from the storage unit, with $S(t)<0$ when charging and $S(t)>0$ when discharging. This takes the losses due to charging, storing and discharging of the energy storage into account. Self-consumption and self-sufficiency can now be defined as:

$$
\begin{gathered}
\varphi_{s c}=\frac{\int_{t=t_{1}}^{t_{2}} M(t) d t}{\int_{t=t_{1}}^{t_{2}} P(t) d t} \\
\varphi_{s s}=\frac{\int_{t=t_{1}}^{t_{2}} M(t) d t}{\int_{t=t_{1}}^{t_{2}} L(t) d t}
\end{gathered}
$$

The relationship between self-consumption and self-sufficiency is therefore: 


$$
\frac{\varphi_{s c}}{\varphi_{s s}}=\frac{\int_{t=t_{1}}^{t_{2}} L(t) d t}{\int_{t=t_{1}}^{t_{2}} P(t) d t}
$$

This equation allows, among other things, for a conversion between self-consumption and selfsufficiency, if the total load and production, or at least the ratio between them, are given. The typical integration period is one year, which is sufficiently long to take seasonal variations into account and to minimize the influence of short-term random fluctuations in generation and demand.

\subsection{Metrics for self-consumption and grid interaction}

The basic self-consumption and self-sufficiency metrics defined above are part of a wider range of metrics describing different aspects of the interplay between on-site power generation and demand. It would lead to far to go into details on all metrics previously described in the literature, but Table 1 shows a classification scheme proposed in [21], where a large set of so-called load matching and grid interaction indicators have been reviewed. Load matching metrics quantify, in different ways, the overlap between the load and generation, which makes self-consumption as defined above a load matching metric. Gridinteraction metrics quantify the net power generation and demand, i.e. the non-overlapping parts. Different metrics have also been reviewed with a focus on load matching metrics in [22], on grid interaction metrics in [23], and on both categories in [24]. Some of these have also been evaluated and compared for simulated and monitored buildings [24-26]. Many of the metrics have been defined to analyze Net Zero Energy Buildings (Net ZEBs), but are equally valid for any building with on-site generation.

The metrics that we focus on in this review, self-consumption and self-sufficiency, belong to category I, being based solely on the on-site profiles. Many metrics in the literature that belong to category I in Table 1 differ mainly by the name. For example, load match index, solar fraction and cover factor mentioned in [21] and self-consumption factor, self-sustenance index and renewable energy fraction mentioned in [22] are all used to describe basically the same thing as the self-sufficiency metric defined above. A more ambitious, generalized definition scheme for self-consumption and self-sufficiency in buildings connected to heating, cooling and power grids and having on-site generation of all three energy forms is presented in a series of studies by Cao et al. [27-30].

It is important to note the difference between load matching and grid interaction. Load matching is mainly important for determining the value of the on-site generation and could be used for this purpose by building designers and building owners, while grid interaction is mainly relevant for the capacity of the distribution grid or the operation of a building in response to time-of-use (TOU) tariffs [21]. Load matching metrics typically quantify the energy over longer periods of time while grid interaction metrics are based on the instantaneous power imported from or exported to the grid. This is also reflected in the metrics in categories III and IV, which use electricity prices to value the on-site matching and power system data to value the system impact of grid interaction. An example of a metric in category III is the mismatch compensation factor [31] that describes which ratio between on-site generation and load is required to make the market value of the on-site generation match the value of the on-site demand. An example of a metric in category IV is the coincidence factor that quantifies the random coincidence of peak powers of a large number of buildings in a grid [21].

\subsection{Important factors affecting self-consumption metrics}

When evaluating and interpreting metrics for PV self-consumption, it is important to be aware of how a couple of factors affect the results:

- Relative sizes of PV power generation and power demand. Self-consumption, as defined above, is normalized by the total power generation, and self-sufficiency by the total power demand. Therefore, increasing the PV generation relative to the demand will always decrease the self-consumption while self-sufficiency will be increased or remain unchanged, cf. Figure 2. The converse holds for a relative increase of the power demand. A Net ZEB that has a perfect annual balance between on-site generation and demand is a special case where the self-consumption is always equal to the selfsufficiency, cf. Figure 3. This is also given by Eq. (7) when the total load equals the total production. 
- Time resolution. In many practical situations, the self-consumption of a building is determined from discrete data series of average power generation and demand, typically hourly values. A lower resolution will always lead to an overestimation of the self-consumption since fluctuations causing mismatch between the generation and load profiles are evened out by averaging, cf. Figure 4 . Several previous studies have investigated the impact of the time resolution on on-site generation analyses [32-36]. A general conclusion seems to be that for individual buildings, sub-hourly data are needed, especially to capture the behavior of high peak powers.

- Number of buildings. The combined load and generation profiles of larger aggregates of buildings are subject to random coincidence, which evens out stochastic fluctuations (cf. Figure 5). However, since smoothing of the PV generation is caused by cloud movements and the highest peak powers occur on clear days, load profiles can be expected to be more affected by the number of buildings. This is especially relevant for grid integration since the ratio of peak generation to peak demand can be expected to get higher when more buildings are aggregated. However, there is a lack of studies analyzing this in detail. 


\section{Behavioral responses to PV systems}

Producing one's own PV electricity is often seen as a life style issue. A common assumption is that a household's intention to become electricity producer is a first step to a change in behavior [37]. In several countries, residential PV systems are still rather scarce and installation of PV, micro wind turbines etc. is then mainly done by so called early adopters. Because of this, some studies choose to focus on intentions and attitudes in general or by different segments [37,38]. Energy consumption needs to be discussed in its social context, as it is a part of a chain of decisions and actions [39,40]. Households' electricity consumption can only be understood as parts of daily habits and routines that families establish in their homes. Previous studies on PV use in households have for example indicated the existence of a rebound effect, where households increased the use of energy-efficient technologies due to savings [41].

An important question regarding self-consumption of PV electricity is the potential impacts that a PV installation has on the energy behavior in households, i.e. how the households interact with the electric power grid. It may be hypothesized that a PV installation in itself, or in combination with electricity production and consumption monitoring and visualization, could spark an interest in the households' energy use and lead to efforts to further reduce it, or to match it to the PV power generation, causing both the total electricity use and the daily load patterns to be different before and after installation. Previous studies on this topic have been summarized and synthesized e.g. in [42-45], indicating interesting but somewhat ambiguous results. An overview of the most relevant studies can be found in Table 2 .

Most of these studies give some indication that both energy reductions and load shifting activities have taken place in households following an installation of micro generation, albeit under differing circumstances. Haas et al. [46], in an early study of Austrian PV installations, had consumption data available before and after installation and could determine the short-term changes in consumption. In particular high-consumption households reduced their consumption following installation of a PV system. Jenny et al. [47] studied an off-grid PV system supplying Cuban rural villages and showed that the community developed and followed rules to adapt the electricity use to the available supply, primarily to reduce consumption peaks. Hondo and Baba [48] did not analyze actual monitoring data but showed through a questionnaire that Japanese households claim to have changed both attitudes and energy-related behaviors following a PV installation.

Two UK studies have presented the most positive results. Keirstead [41] indicated, through selfreported estimates, that households both reduced their energy use after installation (6\% on average) and performed some form of load shifting activity in response to the PV power generation (43\% of the households). Dobbyn and Thomas [49] studied responses to micro generation in general and provided examples of changed attitudes, behaviors and load shifting activities for improved self-consumption. Behavioral changes were noted both in households that had actively chosen to install their own PV system and in households where it had been installed e.g. by a housing association.

In other studies the responses have been few or non-existent. Bahaj and James [50] made a study of nine low-energy social housing homes in the UK equipped with identical PV systems. Despite the fact that the tenants were provided with a display meter and information about how to improve the financial return on the PV systems by avoiding electricity exports, no load shifting activities seem to have taken place. However, a clear reduction in energy use in two households could be seen after an information session, but it was not sustained over a longer period. Most households increased their electricity use over the studied period. In another UK survey [51] early adopters of micro generation (80 households and 30 community projects) claimed to be more aware of energy use but very few (4-5\%) claimed to have made further reductions in energy use. A reason for this may be that the early adopters had already taken significant efficiency measures before installing micro generation.

From these previous studies, it is not possible to draw any general conclusions on the responses to PV installations. Many results have been based on self-reported data through questionnaires and interviews. As also suggested by Sauter and Watson [42] and Stedmon et al. [45] it is important to complement these studies with actual consumption data collected before and after installations of PV systems. Another important issue, also raised by Stedmon et al. [45], that has to be addressed in further research is what causes the behavioral responses if they take place; the PV system in itself or the devices for production and consumption monitoring and visualization that often accompany them. 


\section{Options for improved self-consumption}

Options for increasing self-consumption for residential PV systems and papers that have in some way examined these are presented in Table 3. There are two methods used for improved self-consumption, namely energy storage and load management. These techniques can either be used separately or combined. Load management is hereafter included in the broader concept of demand side management (DSM). A more detailed description of each of these options can be found below.

\subsection{Demand side management (DSM)}

There are several meanings of the concept of demand side management (DSM), where the common denominator is to improve the energy system at the side of consumption [87]. In this review paper, the term is used for load shifting, which can be used to shift the power demands of the loads in a household, for example washing machine and heating, ventilation and air-conditioning (HVAC) systems, from time periods with surplus consumption to periods with surplus PV production. The periods with highest interaction with the power distribution grid (feed in and out) can therefore be decreased. Load shifting can either be achieved manually, where persons switch on electric devices when the sun is shining, or automatically, which requires control algorithms and devices, and sometimes also weather forecasts of ambient temperature and solar irradiation $[71,88]$.

There exist a number of different techniques for DSM, such as direct-load control, load limiters, smart metering and appliances etc. [89]. DSM can also be combined with battery storage to further increase the self-consumption. Control mechanisms for DSM can be included in inverters used for PV, using load shifting, weather forecasts and integrated battery storage to increase the self-consumption [88]. The inverter could thereafter be connected to energy meters at shiftable appliances.

For the papers using DSM, both theoretical algorithms for load shifting and experiments are used for the evaluations. Often, the simulations are done in retrospect when actual consumption and PV production data are given, but the load shifting can also be done in advance if weather forecasts are used.

\subsection{Storage technologies}

There are a few techniques to store energy available on the market with different performance in costs, maximum power, energy capacity, energy density, storage period, response time, efficiency, lifetime in both cycles and years, self-discharge and maturity of the technology [90,91]. For residential PV systems, either hydrogen or solid state battery storage or a combination of both is most suitable for electricity conversion, depending on the period of storage [82]. Batteries have high conversion efficiency but also a relatively high self-discharge - depending on battery technology - over longer periods of time, and are therefore best suited for balancing daily fluctuations [92]. Hydrogen can be produced from electricity using an electrolyzer and stored in a high pressure tank and reconverted into electricity with a fuel cell. Converting electricity into hydrogen and back to electricity again has an efficiency of about 36 percent, which is remarkably lower than for batteries [92]. The rate of discharge with hydrogen storage is however close to zero.

PV electricity can also be stored as heat in for example a water tank to be used when the heat demand is high. Heat storage in a regular water tank, i.e. with moderate temperature, is however not a realistic alternative for electricity conversion and storage due to the low efficiency defined by the Carnot cycle [93].

When using energy storage, it is important not to count losses related to it as self-consumption. [52]. Since management of energy storage, i.e. charging, storing energy and discharging, always leads to losses, it is more efficient to use the generated PV electricity instantly - if possible - instead of storing it for later use. This aspect is important to take into consideration, since energy storage is likely to be used as method of increasing the self-consumption.

\subsubsection{Residential battery storage}

Residential battery storage refers to a stationary battery system used only together with the PV system. There are two main system layouts for residential PV systems with battery storage; either AC coupled where the battery is connected via an inverter and a charge regulator to the AC link of the PV system, or DC coupled where the batteries are connected to the DC link of the inverter [67]. A schematic of the two 
PV-battery system variants is presented in Figure 6. If the PV system and battery storage are connected to only one phase on the AC side of the electric system, the self-consumption will be lower compared to a connection to all three phases, depending on how the power flows are measured [58]. With a single-phase connection, all the electric power will be fed into one phase, and will only supply loads connected to that phase. With a three-phase connection, power is fed into each phase, which distributes it to more loads and potentially increases the self-consumption. However, if the grid interaction is measured as the difference between what is fed in and out as a sum of all the phases, a single- versus three-phase connection does not influence the rate of self-consumption.

Today, the costs of a battery storage system is high - from a few hundred up to more than thousand dollars per kWh of storage capacity - which is one important drawback [94]. At least four aspects besides rated capacity and costs should also be considered: voltage limitation, cycle life, calendar life and efficiency [53].

There are a few different battery technologies available on the market suitable for residential electricity storage, for example lead-acid, lithium-ion (Li-ion), sodium-sulphur (NaS), Nickel-cadmium (NiCd) and Nickel metal hydride (NiMH) [95]. Of these, lead-acid is the most mature storage technique but lithium-ion batteries has the greatest potential for future development and optimization due to high storage efficiency as well as high energy density [96]. The cost of lithium-ion batteries is however high and lead-acid batteries could have an negative environmental impact [97]. Thanks to another current trend, namely the increasing use of electric and hybrid cars which often use high energy-density batteries, there is a potential to utilize used batteries for residential energy storage since the energy density is less important for residential than for transportation applications [53].

The size of the battery is important not only due to storage capacity, but also due to the increasing stress of the system with a smaller battery reducing its lifetime. A larger battery will reduce its depth of discharge of the cycles, which increase the cycle life, even though the effect of deep discharge differs between battery technologies $[98,99]$. With a limitation of the depth of discharge, the actual battery capacity needs to be oversized compared to the usable capacity, resulting in higher investment costs.

New battery technologies suitable for residential energy storage are for example sodium-ion and flow batteries. The sodium-ion technology is comparable to lithium-ion batteries, since both are alkali metals with similar chemical properties, and therefore methods of development used for lithium-ion could be applied for sodium-ion [100]. The higher abundance and lower cost of sodium compared to lithium makes sodium-ion batteries interesting for energy storage, especially since the lower energy density of sodiumion compared to lithium-ion is not a concern [101-104].

\subsubsection{Other storage technologies}

While batteries are best suited for short-term storage due to relatively high rate of self-discharge, longer storage periods require other storage techniques such as hydrogen storage [92,94]. Another advantage of hydrogen storage is the individually scalable components, i.e. electrolyzer, storage tank and fuel cell, in contrast to a battery where there is often a relationship between rated power and stored energy [92].

Moreover, the battery in electric or plug-in hybrid vehicles can be used as energy storage, similar to the use of residential battery storage. One important drawback with electric vehicles as option to increase the residential self-consumption is the high mismatch between the vehicle charging, which often is concentrated to late afternoon, night and early morning, and the PV production, which normally is highest during noon [59]. Therefore, electric vehicle battery storage is not counted as residential battery storage in this paper.

The PV energy can also be converted into heat, for example via direct heating or with a heat pump, and stored in a hot water tank. This could be a good alternative if the house has a high heating demand and a water based heating system combined with a hot water tank. In colder regions at high latitudes, most of the yearly heat demand occurs in the winter when the solar irradiation is low and vice versa. 


\section{Improved self-consumption}

This section presents a summary of the studies that have quantified the self-consumption improvement with the different options presented above. Table 4 gives an overview of the results. The papers are grouped according to the method used to increase the self-consumption, such as residential battery storage and DSM. Moreover, the table gives a summary of the data used for the simulations or experiments, such as installed PV power and yearly consumption, as well as location, simulation or measurement time span and time resolution. Finally, the results of the study are presented as the relative self-consumption, i.e. as selfconsumption as percent of the total PV production, both with and without any measures taken. Only papers with explicit results showing the increase of self-consumption are included in the table and as much information about the papers as obtainable is presented.

Most of the papers with explicit results of the self-consumption increase use energy storage, especially residential battery storage. The papers come from Germany [20,52,57,58,66,67,85], Sweden $[20,60,66,82]$, Spain [73,75], Italy [77], Switzerland [85] and Japan [60]. The last paper is the only one from outside Europe, but since Asia now dominates new PV installations, as presented in the EPIA Market Report 2013 [1], it is likely to change in the future.

Almost every paper presents simulations of measurements over one year with a resolution of one hour or less. By doing long-term simulations, every time of year is simulated or measured. This is of high importance especially for countries at high latitudes with a considerable seasonal variation in solar irradiation, which strongly affects the PV production and thus the self-consumption.

Most of the papers studied a PV-battery system with a storage capacity of 0.5 to $1 \mathrm{kWh}$ times the installed PV capacity in $\mathrm{kW}[52,57,58,66,73,77,81,83,85]$. This means that the storage is used for short term storage, normally shorter than one day. This trend could be explained by the fact that batteries are still expensive compared to the storage capacity [94]. As the name suggests, batteries can only store energy, not produce electric energy. Therefore, the profit - incentives excluded - comes from the difference in selling and buying price of electricity. To make a PV-battery system profitable, there has to be a balance between consumption, PV production and storage capacity, i.e. profits and costs, even though this is not the main point of several of the papers. For the papers with the mentioned relationship between storage capacity and rated PV power, the increase of self-consumption is between 13 and 24 percentage points.

The potential of self-consumption enhancements with residential battery storage, normalized by installed PV power or yearly PV production, and DSM for the studies included are graphically presented in Figure 7, Figure 8 and Figure 9, respectively. The relationship between battery capacity normalized by the rated PV power, and increase in self-consumption of the papers, as seen in Figure 7, is not linear but a clearly distinguishable trend with increasing growth of self-consumption. The conditions in the papers, such as consumption and its pattern, climate zone, initial self-consumption etc., not included in the diagram, have most certainly influences on the results. One way to compensate for different PV production per installed power is to normalize the installed battery capacity (in $\mathrm{kWh}$ ) to the yearly PV production (in MWh), which is shown in Figure 8. However, many of the papers did not present the PV production, and it is therefore difficult to distinguish a significant difference to Figure 7. The values presented in the figures and from which paper they come from are given in Table 5.

Three papers [73,77,81], with four results since one of the papers contained two scenarios [77], presented results for a PV-battery system using DSM. There is no overall trend in the increase of selfconsumption, other than that the increase is higher than for a PV-battery system without DSM. Three results show an increase between 29 and 32 percentage points [73,77], whereas one presents an increase of 15 percentage points [81].

Similar to the results for PV-battery systems using DSM, the results with only DSM also significantly diverge $[19,73,75,77,81]$, as seen in Figure 9. The results vary between an increase of 2 and 15 percentage points. The difference between the four results a-d from Widén are the four PV system sizes indicated in Table 4, with the highest self-consumption increase (a) for $3 \mathrm{~kW} \mathrm{PV}$ and the lowest (d) for 12 $\mathrm{kW}$ PV. The difference between Femia (a) and (b) is the two different households studied, where (a) refers to a household with two working persons and (b) to a household with four persons of whom one is working. The differences between the studies are substantial, and is likely due to a combination of factors such as climatic conditions (between Sweden, Spain and Italy) affecting the availability of irradiance, the overall consumption in the households, how many appliances are considered shiftable, etc. This points out the importance of making more comparable studies where such factors can be controlled. 


\section{Discussion and suggestions for further research}

All of the papers summarized in this review article show a potential of increasing the self-consumption, although the results vary significantly. The reason for this is that many of the studies are based on very particular cases and that many influential factors differ between the studies, e.g. climate, building characteristics, load types, PV system sizes, etc. This suggests that an important further step for the research in this area is to make more comparable studies for more representative samples of buildings and end-users. Some papers did not present all the values, such as yearly PV production. Whereas the rated power of a PV system is fixed, the yearly production corresponds better to location and weather where the PV system is installed. The type of heating system was also not fully stated. This can be of large importance, since use of an electrically heated water tank for heating and tap water has most certainly higher potential for selfconsumption improvement with DSM than use of other heating sources.

Apart from these differences between the studies, it is important to keep in mind when interpreting the results that they are presented, both for battery storage and DSM, as increases in percentage points. It is possible that the original self-consumption affects the total increase. Increases from for example 30 to 50 respective 50 to 70 percentage points are counted as the same increase, although it could be more difficult to raise the self-consumption if it already is high without any arrangements, as seen in Figure 10. As seen in the left case, the time span available for DSM is broader than in the right case. Therefore, DSM probably gives a higher increase in self-consumption - measured as percentage points - when starting at a low level. For energy storage, it is more likely that the whole storage capacity would not be used for this example day for the right scenario than for the left one. It would therefore lower the increase in self-consumption when using battery storage.

Figure 10, as well as Figure 2, discussed previously, once again highlights the importance of considering the ratio between total consumption and total production as expressed by Eq. (7), since this ratio determines the relative sizes of self-consumption and self-sufficiency and the possible improvements in either of these. Since this ratio is affected by different system sizes and by climate differences, it complements the self-consumption and self-sufficiency metrics with important information, especially when comparing different systems and studies.

Another factor affecting the self-consumption is the control strategies for batteries and DSM. The simplest storage management for a PV-battery system is one where the battery is charged when there is a surplus PV production and discharged when there is a surplus consumption. This optimizes the selfconsumption, but there can be other aspects of increasing the self-consumption. If the storage should be used for peak shaving, i.e. reduce the peak surplus PV power injected into the grid, this alternative is not the optimal one when the daily PV production is higher than the storage capacity. Lower feed-in peaks could decrease the stress on the grid, especially if several households with PV systems are connected to the same distribution grid. Instead, an storage management optimized for peak shaving could be used, such as proposed in Schreiber and Hochloff [20]. An example of peak shaving is presented in Figure 11. To achieve this, a weather forecast including for example irradiation and temperature could be used. In this way, the charging pattern could be optimized to minimize the grid interaction. The same battery management could be used when there is a surplus consumption, although consumption could be more difficult to forecast automatically. This is also valid for DSM, where shiftable loads should be distributed during periods with surplus PV production. However, since some of the loads are not perfectly controllable to match periods with surplus PV production, for example a washing machine with a pre-defined program, it would probably be more difficult to even out the grid interaction with DSM than with energy storage. If the storage system is charged directly from the grid, for example in the night, it can be used to further smooth the consumption and thus lower the peaks. With large fluctuations in the electricity price over the day, this storage management could be profitable.

As mentioned, the local climate could have an impact on the rate of self-consumption, especially if the house has electric heating, cooling or ventilation. In cooler regions, a heat pump can be used to store heat in a water tank for heating and tap water. However, the heat demand is higher in the winter whereas the solar irradiation peaks in the summer and thus lowers the self-consumption. In warmer regions where the demand of cooling correlates with the daily and yearly irradiation pattern, the self-consumption can be increased if air-conditioning is used.

As also mentioned previously, when using a PV-storage system, it is important not to count losses in the charging and discharging of the storage as well as self-discharge as self-consumed energy, since this would boost the self-consumption whereas the useful energy would not increase. If the self-consumption is solely based on grid interaction and the power flows are measured at the connection point, there is a risk to include the losses in the assessment. The losses could therefore be counted as a reduced production. 
To further advance the research about self-consumption of PV electricity, the following aspects need to be further investigated:

- Forecasts of solar irradiation to optimize the self-consumption with PV-storage and DSM systems and how to integrate them into energy management systems for buildings, such as examined in [105].

- Further research on how to minimize the peak consumption and production when using a PV system with energy storage or DSM (cf. Schreiber and Hochloff [20]), i.e. not only aim for a high selfconsumption but optimize the grid interaction.

- The aggregate impact on the distribution grid with increased self-consumption of PV electricity in buildings. Self-consumption should be further studied as one possible way to increase the hosting capacity of local electricity distribution grids.

- More comparative studies, both for energy storage and DSM, to make it possible to evaluate where possible similarities and differences originate from. A larger and broader selection and representativity of studied households could also increase the potential of comparison. This would make it possible to apply the results for other households, PV system sizes etc. than the studied ones.

- Further studies on behavioral responses to PV systems should preferably divide households into relevant control groups so that the responses in households with PV can be compared to those in both households with only consumption monitoring and households without both monitoring and PV systems. 


\section{Conclusions}

This review paper has summarized previous research in the field of self-consumption of electricity from residential PV systems. Self-consumption is in this review defined as the share of the PV production that is consumed in the household. The number of published papers about self-consumption is quickly increasing due to increased interest among end-users and the scientific community. The papers summarized use in particular two techniques to increase the self-consumption, namely battery storage and demand side management (DSM).

The majority of the papers using energy storage have batteries with a capacity in $\mathrm{kWh}$ of 0.5 to 1 times the installed PV power in $\mathrm{kW}$. The increase of self-consumption is between 10 and 24 percentage points for the systems referred to. There is a distinguishable trend between the size of battery storage, normalized by the size of PV system, and the increase of self-consumption, although the individual results vary.

The results when applying DSM of a household with a PV system are more varying, but the number of papers found is limited and it is therefore difficult to distinguish a clear trend. There are also a few papers about battery storage combined with DSM. Again, the results differ but show an improvement compared to either battery storage or DSM.

A number of studies have also quantified behavioral responses to PV systems in terms of reductions in energy use or altered load patterns, without any technologies for increased self-consumption. Some of these indicate the existence of behavioral responses, but the overall results are ambiguous and general conclusions cannot be drawn.

Despite the increasing interest in the topic over the last few years, the research of self-consumption of PV electricity is still rather scarce. Also, almost all the papers are from Europe, even though Asia nowadays is the largest market for PV. The field has to be further investigated, especially grid interaction and self-consumption as a way to increase the hosting capacity of distribution grids. Further studies also have to be more comparative to draw general conclusions about the potential for the different technologies. 


\section{Acknowledgements}

This work was carried out as part of the research project Small-scale solar electricity in buildings - Power for change in energy systems and everyday life, financed by the Swedish Energy Agency within the research programme Research and Innovation for Energy Efficient Building and Living. 


\section{References}

[1] European Photovoltaic Industry Association (EPIA). Market Report 2013. 2014 Mar.

[2] Feldman D, Barbose G, Margolis R, Darghouth N, James T, Weaver S, et al. Photovoltaic System Pricing Trends: Historical, Recent, and Near-Term Projections - 2013 Edition [Internet]. Electricity Markets and Policy Group. 2013. Available from: http://emp.lbl.gov/sites/all/files/presentation.pdf [cited 2014 Apr 1].

[3] Lian R. Top 10 PV module suppliers in 2013 [Internet]. PV-Tech.org. 2014. Available from: http://www.pv-tech.org/guest_blog/top_10_pv_module_suppliers_in_2013 [cited 2014 Apr 1].

[4] Goodrich AC, Powell DM, James TL, Woodhouse M, Buonassisi T. Assessing the drivers of regional trends in solar photovoltaic manufacturing. Energy Environ Sci 2013;6(10):2811-21.

[5] IEA PVPS Task 1. Trends 2013 in Photovoltaic Applications. Report No.: 23:2013.

[6] The potential benefits of distributed deneration and rate-related issues that may impede its expansion. U.S. Department of Energy; 2007 Jun.

[7] Büdenbender K, Braun M, Strauß P, Stetz T. Multifunctional PV Systems Offering Additional Functionalities and Improving Grid Integration. Int J Distrib Energy Resour 2011;Vol. 7(2):109_ 28.

[8] Denholm P, Hand M. Grid flexibility and storage required to achieve very high penetration of variable renewable electricity. Energy Policy 2011;39(3):1817-30.

[9] Papaioannou IT, Purvins A, Tzimas E. Demand shifting analysis at high penetration of distributed generation in low voltage grids. Int J Electr Power Energy Syst 2013;44(1):540-6.

[10] Appen J von, Schmiegel AU, Braun M. Impact of PV storage systems on low voltage grids-a study on the influence of PV storage systems on the voltage symmetry of the grid. 27th European Photovoltaic and Solar Energy Conference (PVSEC). Frankfurt, Germany; 2012.

[11] Masson G, Latour M. Self-consumption as the new Holy Grail of the PV industry: From theory to reality. Photovoltaics International. 2012;17th Edition:166-9.

[12] Erban C. kWh output is not the main objective of photovoltaics. 26th European Photovoltaic Solar Energy Conference (PVSEC). Hamburg, Germany; 2011.

[13] Solangi KH, Islam MR, Saidur R, Rahim NA, Fayaz H. A review on global solar energy policy. Renew Sustain Energy Rev 2011;15(4):2149-63.

[14] Hauff J, Rendschmidt D. Enabling the European consumer to generate power for self-consumption. SunEdison, A.T. Kearney; 2011 Nov.

[15] German Federal Ministry for the Environment, Nature Conservation and Nuclear Safety. Renewable Energy Sources Act (EEG) 2012 [Internet]. www.erneuerbare-energien.de. 2013. Available from: http://www.erneuerbare-energien.de/en/topics/acts-and-ordinances/renewableenergy-sources-act/eeg-2012/ [cited 2014 Apr 23].

[16] European Photovoltaic Industry Association (EPIA). Self Consumption of PV Electricity. 2013 Jul.

[17] Solar Energy Industries Association (SEIA). Net Metering by State [Internet]. Available from: http://www.seia.org/research-resources/net-metering-state [cited 2014 Jun 10].

[18] Widén J, Wäckelgård E, Lund PD. Options for improving the load matching capability of distributed photovoltaics: Methodology and application to high-latitude data. Sol Energy 2009;83(11):1953-66. 
[19] Widén J. Improved photovoltaic self-consumption with appliance scheduling in 200 single-family buildings. Appl Energy 2014;126:199-212.

[20] Schreiber M, Hochloff P. Capacity-dependent tariffs and residential energy management for photovoltaic storage systems. IEEE Power and Energy Society General Meeting. 2013.

[21] Salom J, Widén J, Candanedo J, Sartori I, Voss K, Marszal A. Understanding net zero energy buildings: Evaluation of load matching and grid interaction indicators. Proceedings of Building Simulation 2011: 12th Conference of International Building Performance Simulation Association 2011. p. 2514-21.

[22] Cao S. Matching analysis for on-site building energy systems involving energy conversion, storage and hybrid grid connections. Helsinki, Finland: Aalto University; 2014.

[23] Verbruggen B, De Coninck R, Baetens R, Saelens D, Helsen L, Driesen J. Grid impact indicators for active building simulation. Innovative Smart Grid Technologies (ISGT), 2011 IEEE PES. 2011. p. 1-6.

[24] Salom J, Marszal AJ, Candanedo J, Widén J, Byskov Lindberg K, Sartori I. Analysis of load match and grid interaction indicators in Net Zero Energy Buildings with high-resolution data. IEA SHC Task 40 / EBC Annex 52; 2013.

[25] Dar Usman I, Sartori I, Georges L, Novakovic V. Evaluation of load matching and grid interaction index of a Norwegian all-electrical Net-ZEB under stochastic user loads. Proceedings of EuroSun 2012. Rijeka, Croatia; 2012.

[26] Berggren B, Widén J, Karlsson B, Wall M. Evaluation and optimization of a Swedish Net ZEB Using load matching and grid interaction indicators. Proceedings of the First Building Simulation and Optimization Conference. Loughborough, UK; 2012.

[27] Cao S, Hasan A, Sirén K. Analysis and solution for renewable energy load matching for a singlefamily house. Energy Build 2013;65:398-411.

[28] Cao S, Hasan A, Sirén K. On-site energy matching indices for buildings with energy conversion, storage and hybrid grid connections. Energy Build 2013;64:423-38.

[29] Cao S, Hasan A, Sirén K. Matching analysis for on-site hybrid renewable energy systems of office buildings with extended indices. Appl Energy 2014;113:230-47.

[30] Cao S, Mohamed A, Hasan A, Sirén K. Energy matching analysis of on-site micro-cogeneration for a single-family house with thermal and electrical tracking strategies. Energy Build 2014;68(PARTA):351-63.

[31] Lund H, Marszal A, Heiselberg P. Zero energy buildings and mismatch compensation factors. Energy Build 2011;43(7):1646-54.

[32] Hawkes A, Leach M. Impacts of temporal precision in optimisation modelling of micro-Combined Heat and Power. Energy 2005;30(10):1759-79.

[33] Wright A, Firth S. The nature of domestic electricity-loads and effects of time averaging on statistics and on-site generation calculations. Appl Energy 2007;84(4):389-403.

[34] Widén J, Wäckelgård E, Paatero J, Lund P. Impacts of different data averaging times on statistical analysis of distributed domestic photovoltaic systems. Sol Energy 2010;84(3):492-500.

[35] Hoevenaars EJ, Crawford CA. Implications of temporal resolution for modeling renewables-based power systems. Renew Energy 2012;41:285-93.

[36] Cao S, Sirén K. Impact of simulation time-resolution on the matching of PV production and household electric demand. Appl Energy 2014;128:192-208. 
[37] Leenheer J, de Nooij M, Sheikh O. Own power: Motives of having electricity without the energy company. Energy Policy 2011;39(9):5621-9.

[38] Palm J, Tengvard M. Motives for and barriers to household adoption of small-scale production of electricity: examples from Sweden. Sustain Sci Pract Policy 2011;(7:1):6-15.

[39] Weber L. Some reflections on barriers to the efficient use of energy. Energy Policy 1997;25(10):833-5.

[40] Palm J. The building process of single-family houses and the embeddedness (or disembeddedness) of energy. Energy Policy 2013;62:762-7.

[41] Keirstead J. Behavioural responses to photovoltaic systems in the UK domestic sector. Energy Policy 2007;35(8):4128-41.

[42] Sauter R, Watson J. Strategies for the deployment of micro-generation: Implications for social acceptance. Energy Policy 2007;35(5):2770-9.

[43] Keirstead J. What changes, if any, would increased levels of low-carbon decentralised energy have on the built environment? Energy Policy 2008;36(12):4518-21.

[44] Bergman N, Eyre N. What role for microgeneration in a shift to a low carbon domestic energy sector in the UK? Energy Effic 2011;4(3):335-53.

[45] Stedmon AW, Winslow R, Langley A. Micro-generation schemes: user behaviours and attitudes towards energy consumption. Ergonomics 2013;56(3):440-50.

[46] Haas R, Ornetzeder M, Hametner K, Wroblewski A, Hübner M. Socio-economic aspects of the Austrian 200 kWp-photovoltaic-rooftop programme. Sol Energy 1999;66(3):183-91.

[47] Jenny A, López JRD, Mosler H-J. Household energy use patterns and social organisation for optimal energy management in a multi-user solar energy system. Prog Photovolt Res Appl 2006;14(4):353-62.

[48] Hondo H, Baba K. Socio-psychological impacts of the introduction of energy technologies: Change in environmental behavior of households with photovoltaic systems. Appl Energy 2010;87(1):22935.

[49] Dobbyn J, Thomas G. Seeing the light: the impact of micro-generation on the way we use energy. Sustainable Consumption Roundtable; 2005.

[50] Bahaj AS, James PAB. Urban energy generation: The added value of photovoltaics in social housing. Renew Sustain Energy Rev 2007;11(9):2121-36.

[51] Element Energy Ltd. The growth potential for microgeneration in England, Wales and Scotland. Element Energy Ltd.; 2008.

[52] Li J, Danzer MA. Optimal charge control strategies for stationary photovoltaic battery systems. J Power Sources 2014;258:365-73.

[53] Mulder G, Ridder FD, Six D. Electricity storage for grid-connected household dwellings with PV panels. Sol Energy 2010;84(7):1284-93.

[54] Kanamori R, Mizutani N, Ito T. Agent-based electrical power management model for houses equipped with storage battery and photovoltaic units. 2011 IEEE International Conference on Service-Oriented Computing and Applications (SOCA). Irvine, United States; 2011. p. 1-5.

[55] Mulder G, Six D, Claessens B, Broes T, Omar N, Mierlo JV. The dimensioning of PV-battery systems depending on the incentive and selling price conditions. Appl Energy 2013;111:1126-35. 
[56] Park S, Wang Y, Kim Y, Chang N, Pedram M. Battery management for grid-connected PV systems with a battery. Proceedings of the International Symposium on Low Power Electronics and Design. Redondo Beach, United States; 2012. p. 115-20.

[57] Braun M, Büdenbender K, Magnor D, Jossen A. Photovoltaic self-consumption in Germany: using lithium-ion storage to increase self-consumed photovoltaic energy. 24th European Photovoltaic Solar Energy Conference (PVSEC). Hamburg, Germany; 2009.

[58] Bruch M, Müller M. Calculation of the Cost-effectiveness of a PV Battery System. Energy Procedia 2014;46:262-70.

[59] Munkhammar J, Grahn P, Widén J. Quantifying self-consumption of on-site photovoltaic power generation in households with electric vehicle home charging. Sol Energy 2013;97:208-16.

[60] Osawa M, Yoshimi K, Yamashita D, Yokoyama R, Masuda T, Kondou H, et al. Increase the rate of utilization of residential photovoltaic generation by EV charge-discharge control. 2012 IEEE Innovative Smart Grid Technologies - Asia (ISGT Asia). Tianjin, China; 2012. p. 1-6.

[61] Achaibou N, Haddadi M, Malek A. Modeling of Lead Acid Batteries in PV Systems. Energy Procedia 2012;18:538-44.

[62] Bayod-Rújula TA, Haro-Larrodé ME, Martínez-Gracia A. Sizing criteria of hybrid photovoltaicwind systems with battery storage and self-consumption considering interaction with the grid. Sol Energy 2013;98(PC):582-91.

[63] Nge CL, Midtgård O-M, Norum L. Power management of grid-connected photovoltaic inverter with storage battery. 2011 IEEE PES Trondheim PowerTech: The Power of Technology for a Sustainable Society, POWERTECH 2011. 2011.

[64] Song I-B, Jung D-Y, Ji Y-H, Choi S-C, Lee S-W, Won C-Y. A residential 10kWh lithium-polymer battery energy storage system. 8th International Conference on Power Electronics - ECCE Asia: "Green World with Power Electronics", ICPE 2011-ECCE Asia. Jeju, South Korea; 2011. p. 262530.

[65] Thygesen R, Karlsson B. Simulation and analysis of a solar assisted heat pump system with two different storage types for high levels of PV electricity self-consumption. Sol Energy 2014;103:1927.

[66] Waffenschmidt E. Dimensioning of decentralized photovoltaic storages with limited feed-in power and their impact on the distribution grid. 8th International Renewable Energy Storage Conference and Exhibition (IRES 2013). Berlin, Germany; 2013.

[67] Weniger J, Tjaden T, Quaschning V. Sizing of Residential PV Battery Systems. Energy Procedia 2014;46:78-87.

[68] Munkhammar J, Widén J. A flexible Markov-Chain model for simulating demand side management strategies with applications to distributed photovoltaics. Proceedings of the World Renewable Energy Forum. Denver, USA; 2012. p. 1858-65.

[69] Chaabene M, Ammar MB, Elhajjaji A. Fuzzy approach for optimal energy-management of a domestic photovoltaic panel. Appl Energy 2007;84(10):992-1001.

[70] Adika CO, Wang L. Energy management for a customer owned grid-tied photovoltaic micro generator. Power and Energy Society General Meeting (PES), 2013 IEEE. Vancouver, Canada; 2013.

[71] Zong Y, Mihet-Popa L, Kullmann D, Thavlov A, Gehrke O, Bindner HW. Model predictive controller for active demand side management with PV self-consumption in an intelligent building. IEEE PES Innovative Smart Grid Technologies Conference Europe. Berlin, Germany; 2012. 
[72] Castillo-Cagigal M, Gutiérrez A, Monasterio-Huelin F, Caamaño-Martín E, Masa D, JimenézLeube J. A semi-distributed electric demand-side management system with PV generation for selfconsumption enhancement. Energy Convers Manag 2011;52(7):2659-66.

[73] Castillo-Cagigal M, Caamaño-Martín E, Matallanas E, Masa-Bote D, Gutiérrez A, MonasterioHuelin F, et al. PV self-consumption optimization with storage and Active DSM for the residential sector. Sol Energy 2011;85(9):2338-48.

[74] Castillo-Cagigal M, Matallanas E, Gutiérrez A, Monasterio-Huelin F, Caamaño-Martín E, MasaBote D, et al. Heterogeneous collaborative sensor network for electrical management of an automated house with PV energy. Sensors 2011;11(12):11544-59.

[75] Castillo Cagigal M, Matallanas de Avila E, Masa Bote D, Caamaño Martín E, Gutiérrez Martín Á, Monasterio-Huelin Maciá F, et al. Self-consumption enhancement with storage system and demand-side management: GeDELOS-PV system. Proceedings of the 5th International Renewable Energy Storage Conference IRES 2010. Bonn, Germany: E.T.S.I. Telecomunicación (UPM); 2010.

[76] Matallanas E, Castillo-Cagigal M, Gutiérrez A, Monasterio-Huelin F, Caamaño-Martín E, Masa D, et al. Neural network controller for Active Demand-Side Management with PV energy in the residential sector. Appl Energy 2012;91(1):90-7.

[77] Femia N, Toledo D, Zamboni W. Storage unit and load management in photovoltaic inverters for residential application. IECON 2013 - 39th Annual Conference of the IEEE Industrial Electronics Society. Vienna, Austria; 2013. p. 6800-5.

[78] Clastres C, Ha Pham TT, Wurtz F, Bacha S. Ancillary services and optimal household energy management with photovoltaic production. Energy 2009;35(1):55-64.

[79] Barbato A, Capone A, Carello G, Delfanti M, Merlo M, Zaminga A. House energy demand optimization in single and multi-user scenarios. 2011 IEEE International Conference on Smart Grid Communications (SmartGridComm). 2011. p. 345-50.

[80] Sharma S, Galipeau DW. Optimization of residential grid-tied PV systems without net-metering using load management. 2012 IEEE 3rd International Conference on Sustainable Energy Technologies (ICSET). Kathmandu, Nepal; 2012. p. 6-11.

[81] Widén J, Munkhammar J. Evaluating the benefits of a solar home energy management system: Impacts on photovoltaic power production value and grid interaction. Proceedings of the eceee 2013 Summer Study. Toulon/Hyères, France: European Council for an Energy Efficient Economy; 2013.

[82] Parra D, Walker GS, Gillott M. Modeling of PV generation, battery and hydrogen storage to investigate the benefits of energy storage for single dwelling. Sustain Cities Soc 2014;10:1-10.

[83] Vrettos E, Witzig A, Kurmann R, Koch S, Andersson G. Maximizing local PV utilization using small-scale batteries and flexible thermal loads. 28th European Photovoltaic Solar Energy Conference and Exhibition. Paris, France; 2013. p. 4515-26.

[84] Sossan F, Kosek AM, Martinenas S, Marinelli M, Bindner H. Scheduling of domestic water heater power demand for maximizing PV self-consumption using model predictive control. 2013 4th IEEE/PES Innovative Smart Grid Technologies Europe, ISGT Europe 2013. Lyngby, Denmark; 2013.

[85] Williams CJC, Binder JO, Kelm T. Demand side management through heat pumps, thermal storage and battery storage to increase local self-consumption and grid compatibility of PV systems. 2012 3rd IEEE PES International Conference and Exhibition on Innovative Smart Grid Technologies (ISGT Europe). Berlin, Germany; 2012. p. 1-6.

[86] Reynders G, Nuytten T, Saelens D. Potential of structural thermal mass for demand-side management in dwellings. Build Environ 2013;64:187-99. 
[87] Palensky P, Dietrich D. Demand Side Management: Demand Response, Intelligent Energy Systems, and Smart Loads. IEEE Trans Ind Inform 2011;7(3):381-8.

[88] Röpcke I. From power converter to energy manager. Pv Mag 2012(6).

[89] Strbac G. Demand side management: Benefits and challenges. Energy Policy 2008;36(12):441926.

[90] International Energy Agency. Technology Roadmap: Energy Storage. OECD/IEA; 2014 p. $18-24$.

[91] Evans A, Strezov V, Evans TJ. Assessment of utility energy storage options for increased renewable energy penetration. Renew Sustain Energy Rev 2012;16(6):4141-7.

[92] Bocklisch T, Böttiger M, Paulitschke M. Multi-storage Hybrid System Approach and Experimental Investigations. Energy Procedia 2014;46:186-93.

[93] Carnot cycle. Encyclopaedia Britannica. Encyclopaedia Britannica Online Academic Edition. Encyclopædia Britannica Inc.; 2014.

[94] Dunn B, Kamath H, Tarascon J-M. Electrical Energy Storage for the Grid: A Battery of Choices. Science 2011;334(6058):928-35.

[95] Nair N-KC, Garimella N. Battery energy storage systems: Assessment for small-scale renewable energy integration. Energy Build 2010;42(11):2124-30.

[96] Divya KC, Østergaard J. Battery energy storage technology for power systems-An overview. Electr Power Syst Res 2009;79(4):511-20.

[97] McKenna E, McManus M, Cooper S, Thomson M. Economic and environmental impact of leadacid batteries in grid-connected domestic PV systems. Appl Energy 2013;104:239-49.

[98] Jossen A, Garche J, Sauer DU. Operation conditions of batteries in PV applications. Sol Energy 2004;76(6):759-69.

[99] Peterson SB, Apt J, Whitacre JF. Lithium-ion battery cell degradation resulting from realistic vehicle and vehicle-to-grid utilization. J Power Sources 2010;195(8):2385-92.

[100] Hong SY, Kim Y, Park Y, Choi A, Choi N-S, Lee KT. Charge carriers in rechargeable batteries: Na ions vs. Li ions. Energy Environ Sci 2013;6(7):2067-81.

[101] Palomares V, Serras P, Villaluenga I, Hueso KB, Carretero-González J, Rojo T. Na-ion batteries, recent advances and present challenges to become low cost energy storage systems. Energy Environ Sci 2012;5(3):5884.

[102] Pan H, Hu Y-S, Chen L. Room-temperature stationary sodium-ion batteries for large-scale electric energy storage. Energy Environ Sci 2013;6(8):2338-60.

[103] Whitacre JF, Wiley T, Shanbhag S, Wenzhuo Y, Mohamed A, Chun SE, et al. An aqueous electrolyte, sodium ion functional, large format energy storage device for stationary applications. J Power Sources 2012;213:255-64.

[104] Wen Z, Cao J, Gu Z, Xu X, Zhang F, Lin Z. Research on sodium sulfur battery for energy storage. Solid State Ion 2008;179(27-32):1697-701.

[105] Masa-Bote D, Castillo-Cagigal M, Matallanas E, Caamaño-Martín E, Gutiérrez A, MonasterioHuelín F, et al. Improving photovoltaics grid integration through short time forecasting and selfconsumption. Appl Energy 2014;125:103-13. 



\section{Highlights}

- Review of papers examining options for increasing residential PV self-consumption

- Two main options: battery energy storage and demand side management (DSM)

- Higher potential for increased self-consumption with battery storage than DSM

- Further research needed for a comprehensive view of technologies and potential

\section{Figure captions}

Figure 1. Schematic outline of daily net load $(A+C)$, net generation $(B+C)$ and absolute self-consumption (C) in a building with on-site PV. It also indicates the function of the two main options (load shifting and energy storage) for increasing the self-consumption.

Figure 2. Example of a PV system with a low (left) and a high (right) rated power supplying the same building load. Whereas the absolute self-consumption (measured in $\mathrm{kWh}$ ) remains similar, the relative self-consumption (measured as the absolute self-consumption divided with the total PV production) decreases when the rated power of the PV system increases.

Figure 3. Example of the relation between self-sufficiency and self-consumption. For Net Zero Energy Buildings (Net ZEBs), the self-consumption and self-sufficiency are equal according to Eq. (7).

Figure 4. Example of the difference in PV self-consumption when using 10-min (left) and hourly (right) data.

Figure 5. Example of the smoothing effect on the load (L) from averaging over 181 buildings compared to one. The PV power generation $(\mathrm{P})$ is also shown.

Figure 6. Simplified system layouts of AC coupled (left) and DC coupled (right) residential PV battery storage systems. To maximize the power output from the PV modules, a maximum power point tracker (MPPT) has to be used. The figures are based on models published in Weniger et al. [67].

Figure 7. Increase of self-consumption for residential PV systems with either battery storage or battery storage combined with DSM, based on the results presented in Table 4, normalized by installed PV power. Only studies possible to evaluate are presented. Results for PV systems with storage based on electric vehicles are not presented, since they are primarily not used to increase self-consumption. The results are also given in Table 5, which lists the specific studies corresponding to each result. To make the results more comparable, a ratio of 0 to 2 has been chosen. Therefore, the result from Thygesen and Karlsson [65] with a ratio of 4.62 (24 kWh useful storage) or 9.25 (48 kWh nominal storage) is not presented.

Figure 8. Increase of self-consumption for residential PV systems with battery storage, based on the results presented in Table 4, normalized by yearly PV production. Only full-year studies where the PV production is presented are included in the figure. For identification of individual studies, see Table 5.

Figure 9. Increase of self-consumption using solely load shifting (DSM) for a PV-system. Only studies possible to evaluate the change of self-consumption by DSM are presented. The studies are: Widén a-d [19], Widén \& Munkhammar [81], Castillo-Cagigal et al. (1) [75], Castillo-Cagigal et al. (2) [73], Femia et al.a,b [77]

* In Castillo-Cagigal et al. (1) [75], only self-consumption enhancement with DSM for a PV-battery system was found.

Figure 10. Example of two identical PV systems with different total daily consumption. 
Figure 11. Example of grid interaction (dotted line) with a PV-battery system with different rates of charging: in the left case, 100 percent of the surplus PV power is stored until the battery is fully charged, whereas the charging is limited to 40 percent of the surplus PV power in the right case, lowering the peak feed-in power. The total battery capacity is the same in both cases.

\section{Table captions}

Table 1. Categories of load matching and grid interaction metrics previously presented in [21].

Table 2. Previous studies on households' behavioral responses to PV systems. Evidence for or against a response is indicated with ' $y$ ' or ' $n$ ', or with both for conflicting or ambiguous results. If the response was not studied this is indicated with '-'.

Table 3. Options for improved self-consumption in studies covering PV self-consumption or related fields

Table 4. Overview of different studies quantifying increased self-consumption with different options. The papers are presented in following order: first come papers using residential battery storage, thereafter electric vehicles, thermal combined with battery storage, DSM combined with battery storage and finally only DSM. As much information about the papers as obtainable is presented in the table.

Table 5. Authors, references and results for residential PV-battery systems. 


\section{Table 1}

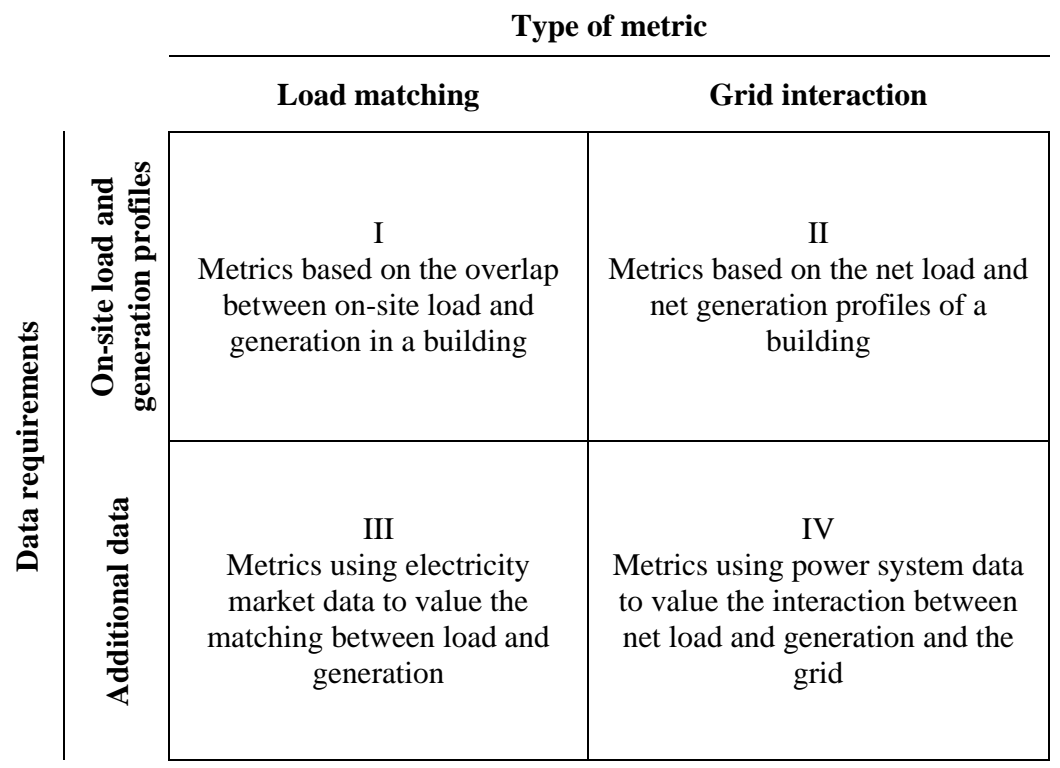

Table 2

\begin{tabular}{|c|c|c|c|c|c|c|c|c|}
\hline \multirow[b]{2}{*}{ Study } & \multirow[b]{2}{*}{ Location } & \multirow[b]{2}{*}{$\begin{array}{l}\text { Year of } \\
\text { investi- } \\
\text { gation }\end{array}$} & \multirow[b]{2}{*}{ Method } & \multirow[b]{2}{*}{$\begin{array}{c}\text { Sample } \\
\text { size }\end{array}$} & \multicolumn{4}{|c|}{ Indicated household response to PV system } \\
\hline & & & & & $\begin{array}{l}\text { Change } \\
\text { in } \\
\text { attitudes }\end{array}$ & $\begin{array}{l}\text { Change } \\
\text { in } \\
\text { behavior }\end{array}$ & $\begin{array}{l}\text { Reduced } \\
\text { energy } \\
\text { use }\end{array}$ & $\begin{array}{c}\text { Load } \\
\text { shifting } \\
\text { activities }\end{array}$ \\
\hline $\begin{array}{c}\text { Haas et al. } \\
{[46]}\end{array}$ & Austria & $1990 \mathrm{~s}$ & $\begin{array}{c}\text { Analysis of } \\
\text { consumption } \\
\text { data }\end{array}$ & 21 & - & - & $\mathrm{y}$ & - \\
\hline $\begin{array}{c}\text { Jenny et al. } \\
\text { [47] }\end{array}$ & Cuba & 2004 & $\begin{array}{l}\text { Questionnaire, } \\
\text { interviews, } \\
\text { analysis of } \\
\text { consumption } \\
\text { data }\end{array}$ & 49 & - & $\mathrm{y}$ & - & $\mathrm{y}$ \\
\hline $\begin{array}{c}\text { Bahaj \& } \\
\text { James [50] }\end{array}$ & UK & 2004 & $\begin{array}{l}\text { Analysis of } \\
\text { consumption } \\
\text { and } \\
\text { production } \\
\text { data }\end{array}$ & 9 & - & $\mathrm{y}$ & $\mathrm{y} / \mathrm{n}$ & $\mathrm{n}$ \\
\hline $\begin{array}{l}\text { Hondo \& } \\
\text { Baba [48] }\end{array}$ & Japan & 2004 & Questionnaire & 200 & $\mathrm{y}$ & $\mathrm{y}$ & - & - \\
\hline $\begin{array}{c}\text { Keirstead } \\
\text { [41] }\end{array}$ & UK & $\begin{array}{l}2004- \\
2005\end{array}$ & $\begin{array}{l}\text { Questionnaire, } \\
\text { interviews }\end{array}$ & 118 & $\mathrm{y}$ & $\mathrm{y}$ & $\mathrm{y}$ & $\mathrm{y}$ \\
\hline $\begin{array}{c}\text { Dobbyn \& } \\
\text { Thomas [49] }\end{array}$ & UK & 2005 & Interviews & 29 & $\mathrm{y}$ & $\mathrm{y}$ & - & $\mathrm{y}$ \\
\hline $\begin{array}{c}\text { Element } \\
\text { Energy [51] }\end{array}$ & UK & 2008 & Questionnaire & 110 & - & - & $y / n$ & - \\
\hline
\end{tabular}


Table 3

\begin{tabular}{|c|c|c|}
\hline $\begin{array}{l}\text { Method for improved } \\
\text { self-consumption }\end{array}$ & Description of technology & $\begin{array}{l}\text { Studies using or } \\
\text { describing the } \\
\text { method }\end{array}$ \\
\hline $\begin{array}{l}\text { Battery storage } \\
\text { (residential or electric } \\
\text { vehicles) }\end{array}$ & $\begin{array}{l}\text { Residential PV system equipped with energy storage using } \\
\text { batteries to optimize the utilization of the PV electricity. }\end{array}$ & {$[18,20,52-67]$} \\
\hline DSM & $\begin{array}{l}\text { Shifting of flexible electric loads in households to optimize } \\
\text { the utilization of the PV production. }\end{array}$ & {$[18,19,68-71]$} \\
\hline DSM and battery storage & $\begin{array}{l}\text { Residential PV system equipped with battery storage } \\
\text { combined with demand side management to optimize the } \\
\text { PV energy utilization. }\end{array}$ & [72-81] \\
\hline $\begin{array}{l}\text { Alternative and } \\
\text { combinations of storage } \\
\text { techniques }\end{array}$ & $\begin{array}{l}\text { Thermal or hydrogen storage, which could be combined } \\
\text { with a battery storage system. }\end{array}$ & {$[65,82-86]$} \\
\hline
\end{tabular}

Table 4

\begin{tabular}{|c|c|c|c|c|c|}
\hline $\begin{array}{l}\text { Author and } \\
\text { reference }\end{array}$ & $\begin{array}{l}\text { Method for } \\
\text { self-consump- } \\
\text { tion }\end{array}$ & $\begin{array}{l}\text { Method for calculation } \\
\text { of self-consumption } \\
\text { and time span }\end{array}$ & $\begin{array}{l}\text { Data sources, } \\
\text { number of samples } \\
\text { and type of building }\end{array}$ & Location & $\begin{array}{l}\text { Results of the study: percent } \\
\text { self-consumption with and } \\
\text { without measures taken }\end{array}$ \\
\hline $\begin{array}{c}\text { Braun et al. } \\
\text { [57] }\end{array}$ & $\begin{array}{l}\text { - Residential } \\
\text { battery } \\
\text { storage, } \\
\text { lithium-ion }\end{array}$ & $\begin{array}{l}\text { - One year simulation } \\
-15 \text { min resolution }\end{array}$ & $\begin{array}{l}\text { - Empirical PV model } \\
\text { - Measured irradiation } \\
\text { - Statistical } \\
\text { consumption profiles } \\
\text { for three types of } \\
\text { different households } \\
\text { - } 5 \mathrm{~kW} \mathrm{PV} \\
\text { systemBattery blocks } \\
\text { of } 2.3 \mathrm{kWh} \text { each } \\
\text { - Yearly consumption } \\
\text { of } 5.5 \mathrm{MWhYearly} \\
\text { PV production of } \\
\text { approx. } 5 \mathrm{MWh}\end{array}$ & $\begin{array}{l}\text { - Kassel, } \\
\text { Germany }\end{array}$ & $\begin{array}{l}\text { - Approx. } 35 \% \text { without storage } \\
\text { - Approx. } 45 \% \text { with } 2.3 \mathrm{kWh} \\
\text { storage } \\
\text { - Approx. } 50 \% \text { with } 4.6 \mathrm{kWh} \\
\text { storage } \\
\text { - Economically interesting with } \\
\text { battery costs below } 350 € / \mathrm{kWh}\end{array}$ \\
\hline $\begin{array}{c}\text { Bruch \& Müller } \\
{[58]}\end{array}$ & $\begin{array}{l}\text { - Residential } \\
\text { battery } \\
\text { storage, } \\
\text { lead acid }\end{array}$ & - One year simulation & $\begin{array}{l}\text { - Production data from } \\
\text { PVGIS } \\
\text { - Consumption data of } \\
\text { a two person } \\
\text { household, yearly } \\
\text { consumption of } \\
\text { approx. } 3.5 \mathrm{MWh} \text {. } \\
\text { - } 6 \mathrm{~kW} \mathrm{PV} \mathrm{system} \\
\text { - Yearly PV production } \\
\text { of approx. 5.8 MWh }\end{array}$ & $\begin{array}{r}\text { - Southern } \\
\text { Germany }\end{array}$ & $\begin{array}{l}-29 \% \text { without storage } \\
-47 \% \text { with } 2 \mathrm{kWh} \text { storage } \\
-51 \% \text { with } 4 \mathrm{kWh} \text { storage }\end{array}$ \\
\hline
\end{tabular}




\begin{tabular}{|c|c|c|c|c|c|}
\hline $\begin{array}{l}\text { Author and } \\
\text { reference }\end{array}$ & $\begin{array}{l}\text { Method for } \\
\text { self-consump- } \\
\text { tion }\end{array}$ & $\begin{array}{l}\text { Method for calculation } \\
\text { of self-consumption } \\
\text { and time span }\end{array}$ & $\begin{array}{l}\text { Data sources, } \\
\text { number of samples } \\
\text { and type of building }\end{array}$ & Location & $\begin{array}{l}\text { Results of the study: percent } \\
\text { self-consumption with and } \\
\text { without measures taken }\end{array}$ \\
\hline $\begin{array}{l}\text { Li \& Danzer } \\
{[52]}\end{array}$ & $\begin{array}{l}\text { - Residential } \\
\text { battery storage }\end{array}$ & $\begin{array}{l}\text { - Dynamic programming } \\
-15 \text { min resolution } \\
\text { - Simulations for two days }\end{array}$ & $\begin{array}{l}\text { - Simulated PV } \\
\text { production using } \\
\text { PVsyst } \\
\text { - Two daily } \\
\text { consumption and PV } \\
\text { production profiles, } \\
\text { one with high and one } \\
\text { with low natural self- } \\
\text { consumption, of a } \\
\text { four person household } \\
\text { - } 3.5 \text { kW PV system } \\
\text { - } 3.3 \text { kWh battery } \\
\text { storage } \\
\text { - Yearly consumption } \\
\text { of } 4 \text { MWh } \\
\text { - Yearly PV production } \\
\text { of approx. } 4 \text { MWh }\end{array}$ & $\begin{array}{r}\text { - Stuttgart, } \\
\text { Germany }\end{array}$ & $\begin{array}{l}\text { - Results for a day with low natural } \\
\text { self-consumption } \\
\circ 17 \% \text { without storage } \\
\circ 33 \% \text { with charging strategy for } \\
\text { optimized self-consumption } \\
\text { - Results for a day with high natural } \\
\text { self-consumption } \\
\circ 34 \% \text { without storage } \\
\circ \quad 64 \% \text { with charging strategy for } \\
\text { optimized self-consumption } \\
\text { - Mean self-consumption of the two } \\
\text { days } \\
\circ 26 \% \text { without storage } \\
\circ 50 \% \text { with charging strategy for } \\
\text { optimized self-consumption }\end{array}$ \\
\hline $\begin{array}{l}\text { Schreiber \& } \\
\text { Hochloff } \\
{[20]}\end{array}$ & $\begin{array}{l}\text { - Residential } \\
\text { battery storage }\end{array}$ & $\begin{array}{l}\text { - One year time span } \\
-15 \text { min resolution } \\
\text { consumption of one } \\
\text { household } \\
\text { - Numeric simulation }\end{array}$ & $\begin{array}{l}\text { - Measured } \\
\text { consumption } \\
\text { - Simulated PV } \\
\text { production using } \\
\text { Transvalor } \\
-4.1 \mathrm{~kW} \mathrm{PV} \mathrm{system} \\
-7.4 \mathrm{kWh} \text { battery } \\
\text { - Yearly consumption } \\
\text { of approx. } 4.3 \mathrm{MWh}\end{array}$ & - Germany & $\begin{array}{l}-31 \% \text { without storage } \\
-72 \% \text { with storage }\end{array}$ \\
\hline $\begin{array}{l}\text { Waffenschmidt } \\
\text { [66] }\end{array}$ & $\begin{array}{l}\text { - Residential } \\
\text { battery storage }\end{array}$ & $\begin{array}{l}\text { - One year simulation in } \\
\text { NEPLAN } \\
-15 \text { minute resolution }\end{array}$ & $\begin{array}{l}\text { - Measured PV } \\
\text { production } \\
-1.1 \mathrm{~kW} \mathrm{PV} \mathrm{system} \\
\text { - Yearly consumption } \\
\text { of } 1 \mathrm{MWh} \\
\text { - Yearly PV production } \\
\text { of } 1.1 \mathrm{MWh} \\
-1 \mathrm{kWh} \text { battery } \\
\text { storage } \\
\text { - Rated power of the } \\
\text { PV system, yearly } \\
\text { consumption and size } \\
\text { of battery storage are } \\
\text { linearly scalable }\end{array}$ & - Germany & $\begin{array}{l}\text { Approx. } 38 \% \text { without storage } \\
\text { Approx. } 57 \% \text { with storage }\end{array}$ \\
\hline $\begin{array}{l}\text { Weniger et al. } \\
\text { [67] }\end{array}$ & $\begin{array}{l}\text { - Residential } \\
\text { battery } \\
\text { storage, } \\
\text { lithium-based }\end{array}$ & $\begin{array}{l}\text { - One year simulations } \\
\text { - One minute resolution }\end{array}$ & $\begin{array}{l}\text { - Measured irradiation } \\
\text { data } \\
-3.2 \mathrm{~kW} \text { PV system } \\
\text { (most cost-efficient) } \\
\text { - } 4.4 \mathrm{kWh} \text { battery } \\
\text { storage (most cost- } \\
\text { effective) } \\
\text { - Yearly consumption } \\
\text { of } 4 \mathrm{MWh} \\
\text { - Yearly PV production } \\
\text { of } 3.3 \mathrm{MWh}\end{array}$ & $\begin{array}{c}\text { - North-east } \\
\text { Germany }\end{array}$ & $\begin{array}{l}\text { Approx. } 35 \% \text { without storage } \\
\text { Approx. } 65 \% \text { with storage }\end{array}$ \\
\hline $\begin{array}{l}\text { Munkhammar et } \\
\text { al. } \\
\text { [59] }\end{array}$ & $\begin{array}{l}\text { - Battery storage } \\
\text { (electric } \\
\text { vehicles) }\end{array}$ & $\begin{array}{l}\text { - Markov-chain model } \\
\text { - One minute resolution } \\
\text { - One year simulation }\end{array}$ & $\begin{array}{l}\text { - Measured irradiation } \\
\text { - Synthetic } \\
\text { consumption data } \\
\text { - Total yearly } \\
\text { consumption of } 5.7 \\
\text { MWh (electric car + } \\
\text { household) } \\
\text { - Maximum } 14 \mathrm{kWh} \\
\text { battery storage } \\
\text { - Two PV sizes: } 4.3 \mathrm{~kW} \\
\text { and } 5.8 \mathrm{~kW}\end{array}$ & $\begin{array}{l}\text { - Uppsala, } \\
\text { Sweden }\end{array}$ & $\begin{array}{l}\text { - Results for a house with a } 4.3 \mathrm{~kW} \\
\text { PV system: } \\
\text { ○ } 31 \% \text { without battery storage } \\
\circ 34 \% \text { with battery storage } \\
\text { - Results for a house with a } 5.8 \mathrm{~kW} \\
\text { PV system } \\
\text { ○ } 25 \% \text { without battery storage } \\
\text { ○ } 28 \% \text { with battery storage }\end{array}$ \\
\hline
\end{tabular}




\begin{tabular}{|c|c|c|c|c|c|}
\hline $\begin{array}{l}\text { Author and } \\
\text { reference }\end{array}$ & $\begin{array}{l}\text { Method for } \\
\text { self-consump- } \\
\text { tion }\end{array}$ & $\begin{array}{l}\text { Method for calculation } \\
\text { of self-consumption } \\
\text { and time span }\end{array}$ & $\begin{array}{l}\text { Data sources, } \\
\text { number of samples } \\
\text { and type of building }\end{array}$ & Location & $\begin{array}{l}\text { Results of the study: percent } \\
\text { self-consumption with and } \\
\text { without measures taken }\end{array}$ \\
\hline $\begin{array}{c}\text { Osawa et al. } \\
{[60]}\end{array}$ & $\begin{array}{l}\text { - Battery storage } \\
\text { (electric } \\
\text { vehicles) }\end{array}$ & $\begin{array}{l}\text { - Algorithm controlling the } \\
\text { EV charge-discharge } \\
\text { - One year time span } \\
\text { - Hourly resolution }\end{array}$ & $\begin{aligned}- & \text { Measurements of } \\
& \text { consumption for } 50 \\
& \text { houses } \\
- & \text { Measured irradiation } \\
- & 3.4 \mathrm{~kW} \text { PV system } \\
- & 24 \mathrm{kWh} \text { lithium-ion } \\
& \text { battery (vehicle) }\end{aligned}$ & $\begin{array}{c}- \text { Tokyo, } \\
\text { Japan }\end{array}$ & $\begin{array}{l}-41 \% \text { without electric vehicle } \\
-79 \% \text { with optimized } \\
\text { charge/discharge control and } \\
\text { utilization of the electric vehicle } \\
\text { battery }\end{array}$ \\
\hline $\begin{array}{c}\text { Thygesen \& } \\
\text { Karlsson } \\
{[65]}\end{array}$ & $\begin{array}{l}\text { - Thermal and } \\
\text { residential } \\
\text { battery storage }\end{array}$ & $\begin{array}{l}\text { - Parametric analysis } \\
\text { - Three minute resolution } \\
\text { - One year analysis }\end{array}$ & $\begin{array}{l}\text { - Irradiation data from } \\
\text { Meteonorm } \\
-5.19 \mathrm{~kW} \mathrm{PV} \mathrm{system} \\
-48 \mathrm{kWh} \text { battery } \\
\text { storage (of which } 24 \\
\text { kWh can be used) } \\
\text { - } 185 \text { litre hot water } \\
\text { storage tank } \\
\text { - Yearly consumption } \\
\text { of approx. } 10.6 \mathrm{MWh} \\
\text { - Yearly PV production } \\
\text { of approx. 5.1 MWh }\end{array}$ & $\begin{array}{c}\text { - Västerås, } \\
\text { Sweden }\end{array}$ & $\begin{array}{l}-56 \% \text { without storage } \\
-88 \% \text { with thermal storage } \\
-89 \% \text { with battery storage }\end{array}$ \\
\hline $\begin{array}{c}\text { Vrettos et al. } \\
{[83]}\end{array}$ & $\begin{array}{l}\text { - Thermal and } \\
\text { residential } \\
\text { battery storage }\end{array}$ & $\begin{array}{l}\text { - Algorithms for batteries } \\
\text { and flexible thermal } \\
\text { loads } \\
\text { - One year simulation }\end{array}$ & $\begin{array}{l}\text { - PV production } \\
\text { calculation using } \\
\text { Polysun } \\
\text { - Single-family house, } \\
\text { two parents and one } \\
\text { child } \\
-10.8 \mathrm{~kW} \mathrm{PV} \mathrm{system} \\
-3.3 \mathrm{~kW} \text { (electric) heat } \\
\text { pump } \\
-6 \mathrm{kWh} \text { battery storage } \\
\text { - Yearly consumption } \\
\text { of approx. } 11 \mathrm{MWh}\end{array}$ & $\begin{array}{l}- \text { Switzer- } \\
\text { land }\end{array}$ & $\begin{array}{l}\text { - } 20 \% \text { without battery storage, } \\
\text { without optimized algorithm for the } \\
\text { heat pump } \\
\text { - } 37 \% \text { with optimized algorithms for } \\
\text { battery storage and utilization of } \\
\text { the heat pump } \\
\text { - Battery storage has a higher } \\
\text { potential than optimized utilization } \\
\text { of the heat pump }\end{array}$ \\
\hline $\begin{array}{l}\text { Williams et al. } \\
{[85]}\end{array}$ & $\begin{array}{l}\text { - Thermal and } \\
\text { residential } \\
\text { battery storage }\end{array}$ & $\begin{array}{l}\text { - Algorithms for batteries } \\
\text { and heat pump } \\
\text { - One year simulation }\end{array}$ & $\begin{array}{l}\text { - Simulated PV } \\
\text { production using a } \\
\text { synthetic weather } \\
\text { model and the } \\
\text { program PVsyst } \\
\text { - Four person } \\
\text { household } \\
\text { - } 3.9 \mathrm{~kW} \text { PV system } \\
\text { (Yearly production of } \\
\text { 3.9 MWh) } \\
- \text { Yearly electric } \\
\text { consumption } \\
\text { o } 3.9 \text { MWh (without } \\
\text { heat pump) } \\
-2.5 \mathrm{kWh} \text { battery } \\
\text { storage }\end{array}$ & $\begin{array}{r}\text { - Stuttgart, } \\
\text { Germany }\end{array}$ & $\begin{array}{l}\text { - Approx. } 37 \% \text { without battery } \\
\text { storage, without thermal load/heat } \\
\text { pump } \\
\text { - Approx. } 55 \% \text { with battery storage, } \\
\text { without thermal load/heat pump }\end{array}$ \\
\hline $\begin{array}{c}\text { Castillo-Cagigal } \\
\text { et al. }{ }^{1} \\
{[73]}\end{array}$ & $\begin{array}{l}\text { - DSM and } \\
\text { residential } \\
\text { battery } \\
\text { storage, lead } \\
\text { acid }\end{array}$ & $\begin{array}{l}\text { - Experimental results } \\
\text { during one week }\end{array}$ & $\begin{array}{l}-5 \mathrm{kWh} \text { PV system } \\
-5.4 \mathrm{kWh} \text { battery } \\
\text { storage } \\
\text { - Daily load between } 10 \\
\text { and } 11 \mathrm{kWh}\end{array}$ & $\begin{array}{l}\text { - Madrid, } \\
\text { Spain }\end{array}$ & $\begin{aligned}- & 15 \% \text { without storage, without } \\
& \text { DSM } \\
- & 27 \% \text { without storage, with DSM } \\
- & 35 \% \text { with storage, without DSM } \\
- & 44 \% \text { with storage, with DSM }\end{aligned}$ \\
\hline
\end{tabular}

\footnotetext{
${ }^{1}$ According to the definitions of self-consumption and self-sufficiency in section 2.1, the results in Castillo-Cagigal et al. [73] are presented as self-sufficiency and the results have therefore been recalculated with Eq. (7).
} 


\begin{tabular}{|c|c|c|c|c|c|}
\hline $\begin{array}{l}\text { Author and } \\
\text { reference }\end{array}$ & $\begin{array}{l}\text { Method for } \\
\text { self-consump- } \\
\text { tion }\end{array}$ & $\begin{array}{l}\text { Method for calculation } \\
\text { of self-consumption } \\
\text { and time span }\end{array}$ & $\begin{array}{l}\text { Data sources, } \\
\text { number of samples } \\
\text { and type of building }\end{array}$ & Location & $\begin{array}{l}\text { Results of the study: percent } \\
\text { self-consumption with and } \\
\text { without measures taken }\end{array}$ \\
\hline $\begin{array}{l}\text { Castillo-Cagigal } \\
\text { et al. }{ }^{1} \\
{[75]}\end{array}$ & $\begin{array}{l}\text { - DSM and } \\
\text { residential } \\
\text { battery } \\
\text { storage, lead } \\
\text { acid }\end{array}$ & $\begin{array}{l}\text { - Experimental results } \\
\text { from two weeks of } \\
\text { operation as comparison, } \\
\text { presented as daily } \\
\text { average }\end{array}$ & $\begin{array}{l}\text { - Daily loads between } \\
11 \text { and } 13 \mathrm{kWh} \\
-5.55 \mathrm{~kW} \text { PV system } \\
-5.4 \mathrm{kWh} \text { battery } \\
\text { storage }\end{array}$ & $\begin{array}{l}\text { - Madrid, } \\
\text { Spain }\end{array}$ & $\begin{array}{l}-33 \% \text { with storage, without DSM } \\
-42 \% \text { with storage, with DSM } \\
\text { No results presented for a PV system } \\
\text { without storage }\end{array}$ \\
\hline $\begin{array}{c}\text { Femia et al. } \\
{[77]}\end{array}$ & $\begin{array}{l}\text { - DSM and } \\
\text { residential } \\
\text { battery } \\
\text { storage, lead } \\
\text { acid }\end{array}$ & $\begin{array}{l}\text { - Numerical simulation on } \\
\text { fictive houses } \\
\text { - One year simulation }\end{array}$ & $\begin{array}{l}- \text { Two households } \\
\circ \text { two persons, both } \\
\text { working during } \\
\text { the day, yearly } \\
\text { consumption of } \\
2.3 \mathrm{MWh} \\
\circ \text { Four persons, one } \\
\text { working during } \\
\text { the day, yearly } \\
\text { consumption of } \\
5.0 \mathrm{MWh} \\
-2.9 \mathrm{~kW} \text { PV system } \\
-2.2 \mathrm{kWh} \text { battery } \\
\text { storage }\end{array}$ & $\begin{array}{l}\text { - Napoli, } \\
\text { Italy }\end{array}$ & $\begin{array}{l}\text { House with two persons: } \\
-16 \% \text { without storage, without } \\
\text { DSM } \\
-31 \% \text { without storage, with DSM } \\
-33 \% \text { with storage, without DSM } \\
-48 \% \text { with storage, with DSM } \\
\text { House with four persons: } \\
\text { - } 44 \% \text { without storage, without } \\
\text { DSM } \\
-53 \% \text { without storage, with DSM } \\
-65 \% \text { with storage, without DSM } \\
-73 \% \text { with storage, with DSM }\end{array}$ \\
\hline $\begin{array}{c}\text { Widén \& } \\
\text { Munkhammar } \\
\text { [81] }\end{array}$ & $\begin{array}{l}\text { - DSM and } \\
\text { residential } \\
\text { battery } \\
\text { storage, lead } \\
\text { acid }\end{array}$ & $\begin{array}{l}\text { - One year simulation } \\
\text { - } 10 \text { minutes resolution } \\
\text { - Load shifting algorithm }\end{array}$ & $\begin{array}{l}\text { - Measured } \\
\text { consumption from } 20 \\
\text { detached single- } \\
\text { family houses } \\
\text { - Measured } \\
\text { meteorological data } \\
\text { - } 5 \mathrm{~kW} \text { PV system } \\
\text { - } 5 \mathrm{kWh} \text { battery storage } \\
\text { - Yearly PV production } \\
\text { of } 4.9 \mathrm{MWh}\end{array}$ & $\begin{array}{l}\text { - Sweden, } \\
\text { several } \\
\text { locations }\end{array}$ & $\begin{aligned} &- 50 \% \text { without storage, without } \\
& \text { DSM } \\
&- 53 \% \text { without storage, with DSM } \\
& \text { - Approx. } 63 \% \text { with storage, without } \\
& \text { DSM } \\
& \text { - Approx. } 65 \% \text { with storage, with } \\
& \text { DSM }\end{aligned}$ \\
\hline $\begin{array}{c}\text { Widén } \\
\text { [19] }\end{array}$ & - DSM & $\begin{array}{l}\text { - Load shifting algorithm } \\
\text { - One year simulation } \\
\text { - } 10 \text { min resolution }\end{array}$ & $\begin{array}{l}\text { - Measured load } \\
\text { profiles for multiple } \\
\text { appliances } \\
\text { - } 200 \text { Swedish single- } \\
\text { family households } \\
\text { - Measured } \\
\text { meteorological data } \\
\text { - } 4 \text { sizes of PV systems: } \\
\text { 3,6, } 9 \text { and } 12 \mathrm{~kW}\end{array}$ & $\begin{array}{l}\text { - Sweden, } \\
\text { several } \\
\text { locations }\end{array}$ & $\begin{array}{l}\text { Average results } \\
3 \mathrm{~kW} \text { PV system: } \\
-63 \% \text { without DSM } \\
-67 \% \text { with DSM } \\
6 \mathrm{~kW} \text { PV system } \\
-45 \% \text { without DSM } \\
-48 \% \text { with DSM } \\
9 \mathrm{~kW} \text { PV system } \\
-35 \% \text { without DSM } \\
-37 \% \text { with DSM } \\
12 \mathrm{~kW} \text { PV system } \\
-29 \% \text { without DSM } \\
-31 \% \text { with DSM }\end{array}$ \\
\hline
\end{tabular}

\footnotetext{
${ }^{1}$ According to the definitions of self-consumption and self-sufficiency in section 2.1, the results in Castillo-Cagigal et al. [75] are presented as self-sufficiency and the results have therefore been recalculated with Eq. (7).
} 


\section{Table 5}

\begin{tabular}{|c|c|c|c|}
\hline Author & $\frac{\text { Battery capacity }(\mathrm{kWh})}{\text { PV peak power }(\mathbf{k W})}$ & $\frac{\text { Battery capacity }(\mathrm{kWh})}{\text { PV production }(\mathrm{MWh})}$ & $\begin{array}{l}\text { Percentage point increase of } \\
\text { self-consumption }\end{array}$ \\
\hline Bruch \& Müller [58] & 0.33 & 0.34 & 18 \\
\hline Braun et al. [57] & 0.46 & 0.46 & 10 \\
\hline Vrettos et al. [83] & 0.56 & - & 17 \\
\hline Williams et al. [85] & 0.64 & 0.64 & 18 \\
\hline Bruch \& Müller [58] & 0.67 & 0.69 & 22 \\
\hline Femia et al. [77] & 0.76 & - & 17 (32 combined with DSM) \\
\hline Femia et al. [77] & 0.76 & - & 21 (29 combined with DSM) \\
\hline Waffenschmidt [66] & 0.91 & 0.91 & 19 \\
\hline Braun et al. [57] & 0.92 & 0.92 & 15 \\
\hline Li \& Danzer [52] & 0.94 & 0.83 & 24 \\
\hline Castillo-Cagigal et al. [73] & 0.97 & - & 20 (29 combined with DSM) \\
\hline Widén \& Munkhammar [81] & 1 & 1 & 13 (15 combined with DSM) \\
\hline Weniger et al. [67] & 1.38 & 1.33 & 30 \\
\hline Schreiber \& Hochloff [20] & 1.80 & - & 41 \\
\hline Thygesen \& Karlsson [65] & 4.62/9.25 (24/48 kWh storage) & 4,71/9.41 (24/48 kWh) & 33 \\
\hline
\end{tabular}




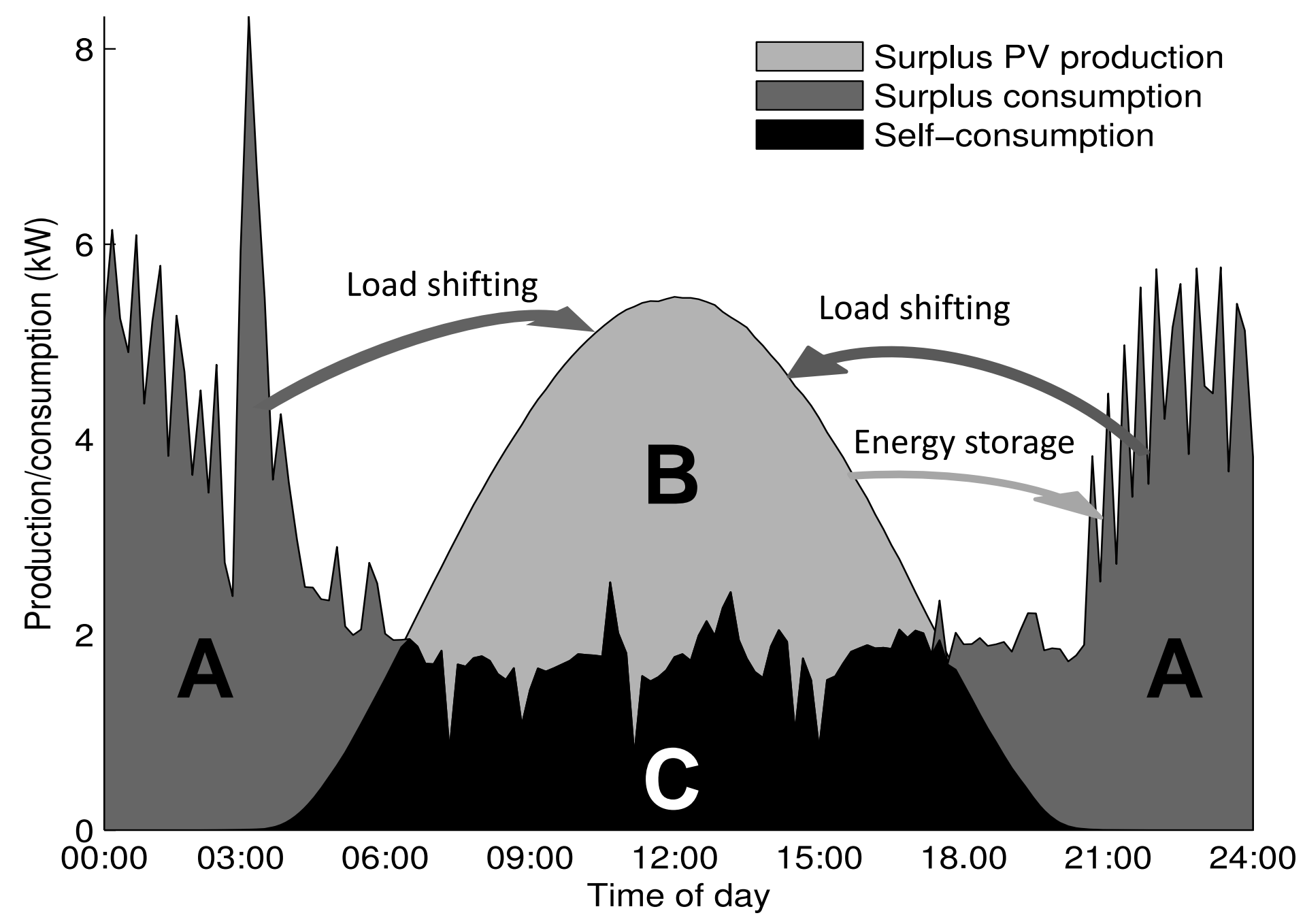



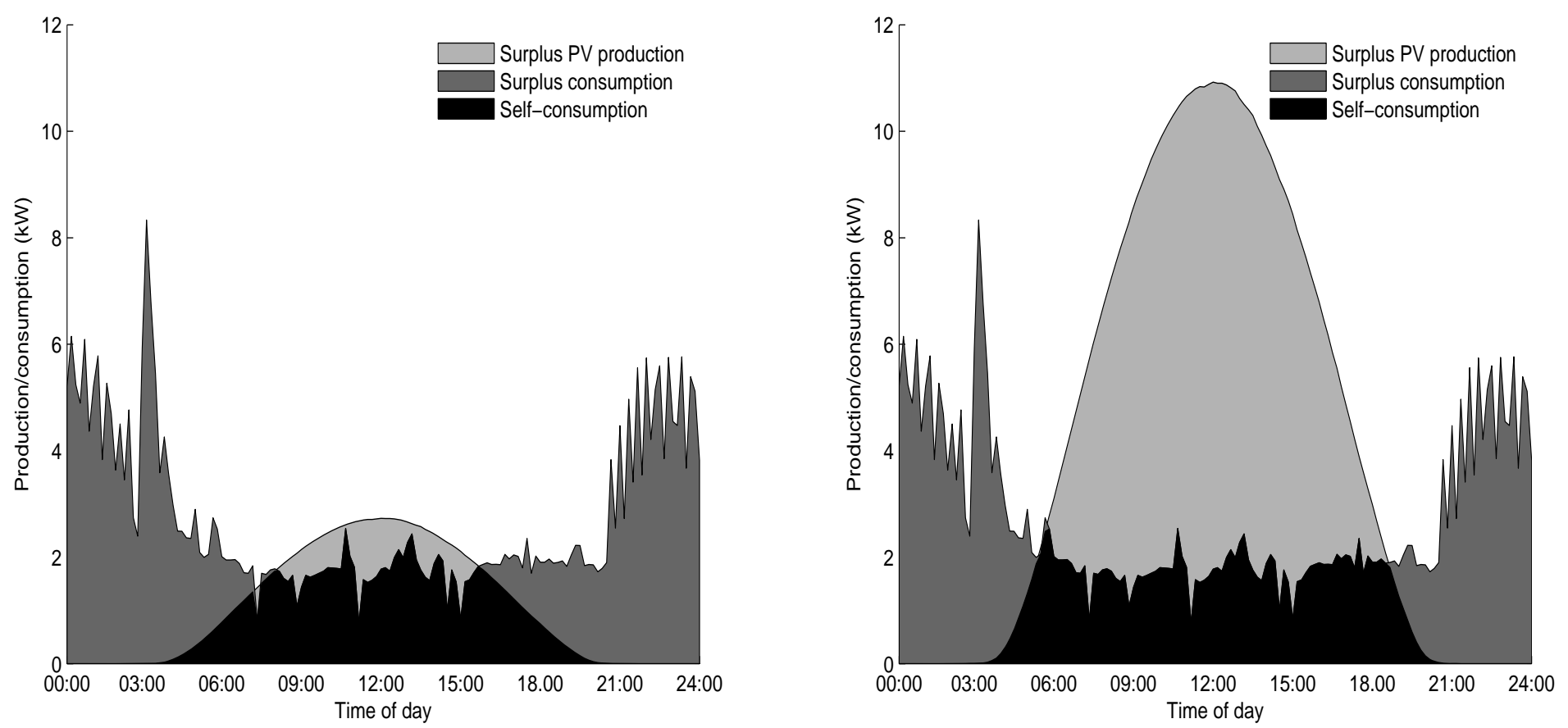


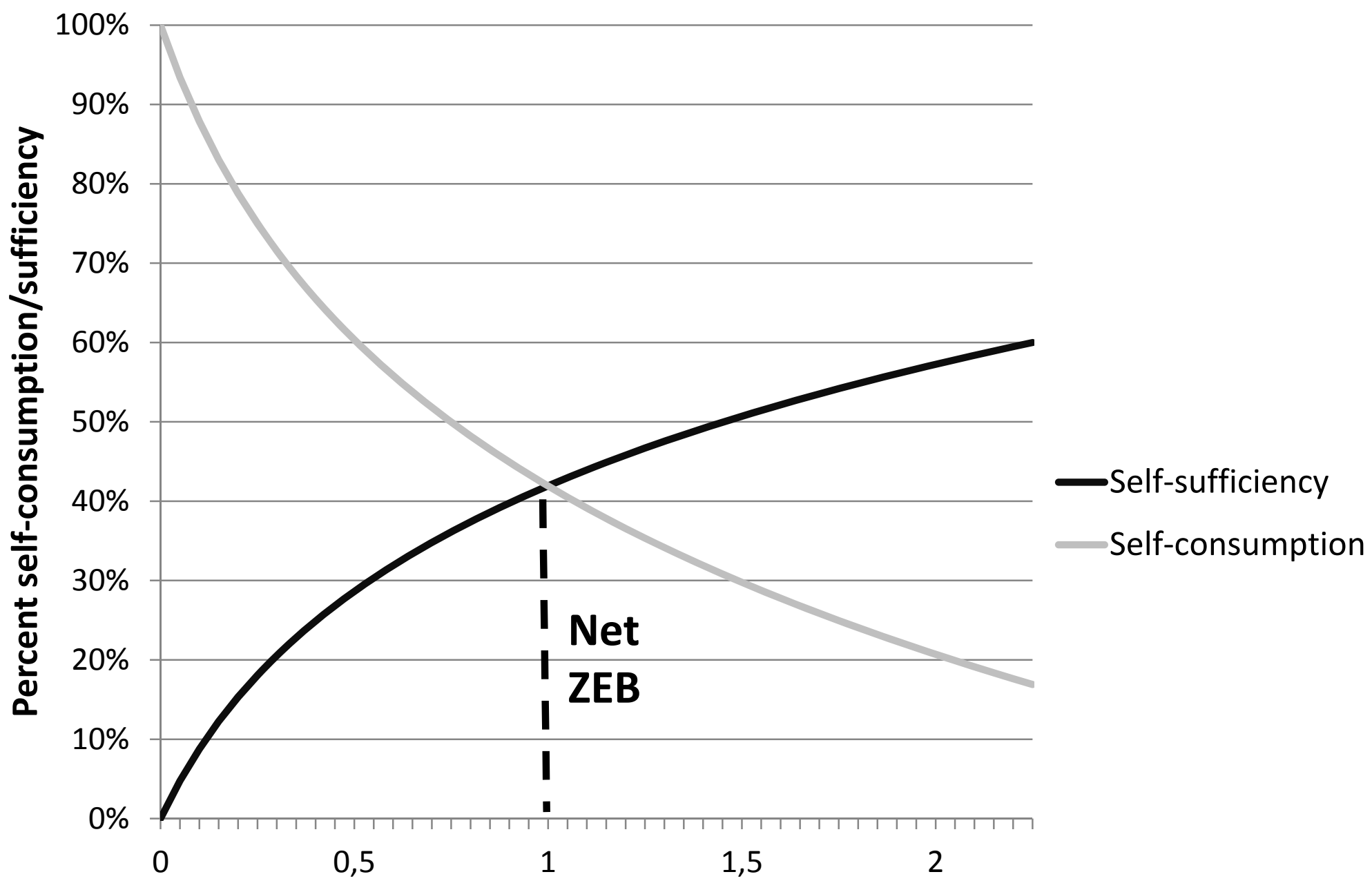

Yearly PV production normalized by yearly electricity consumption 

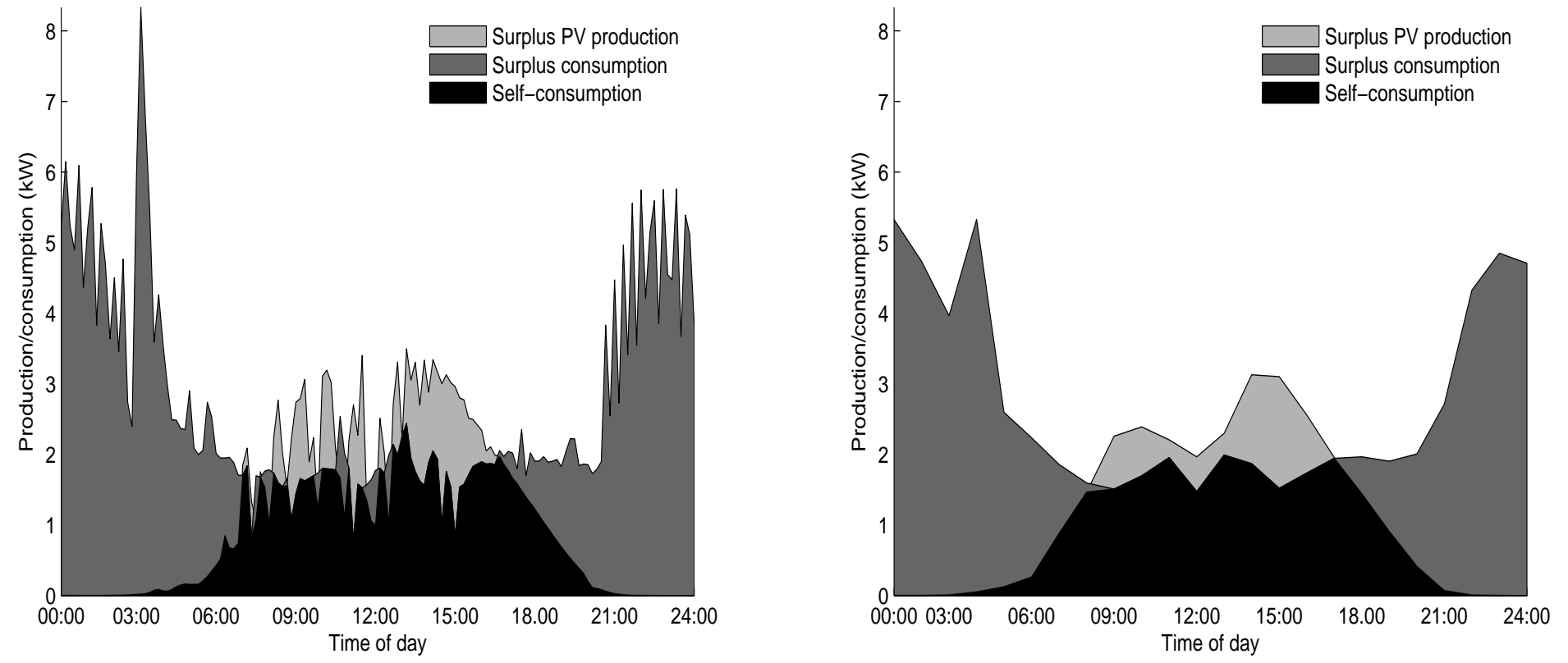


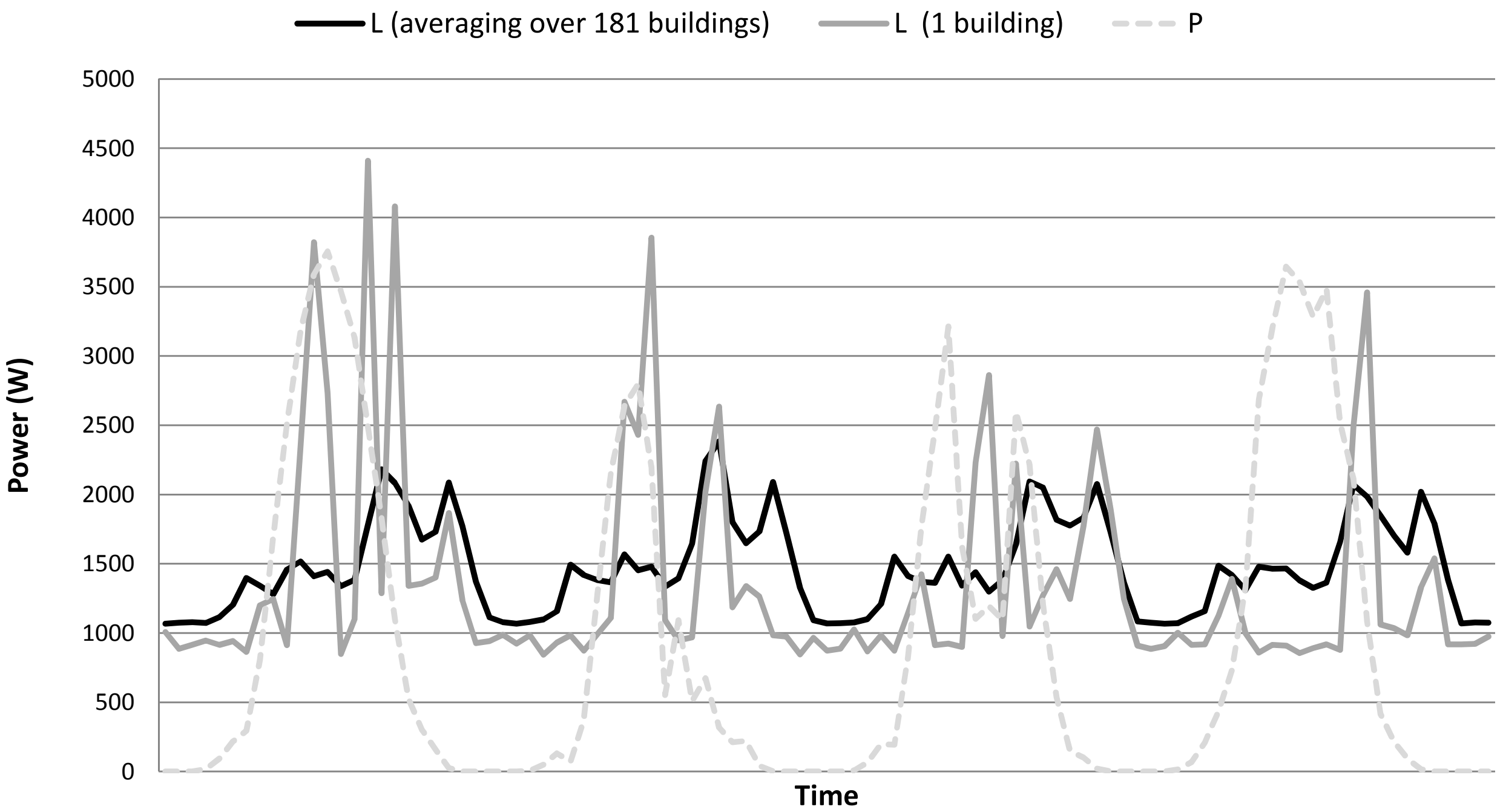




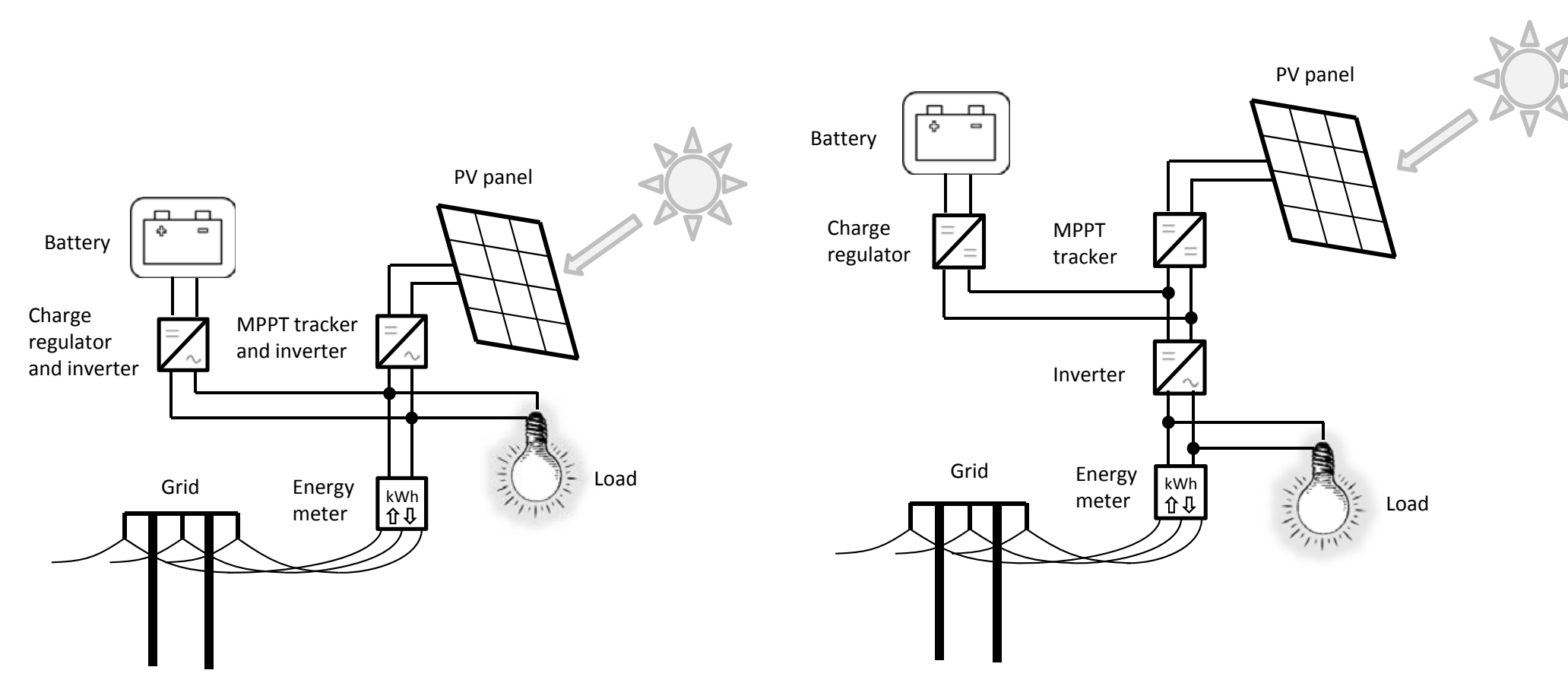




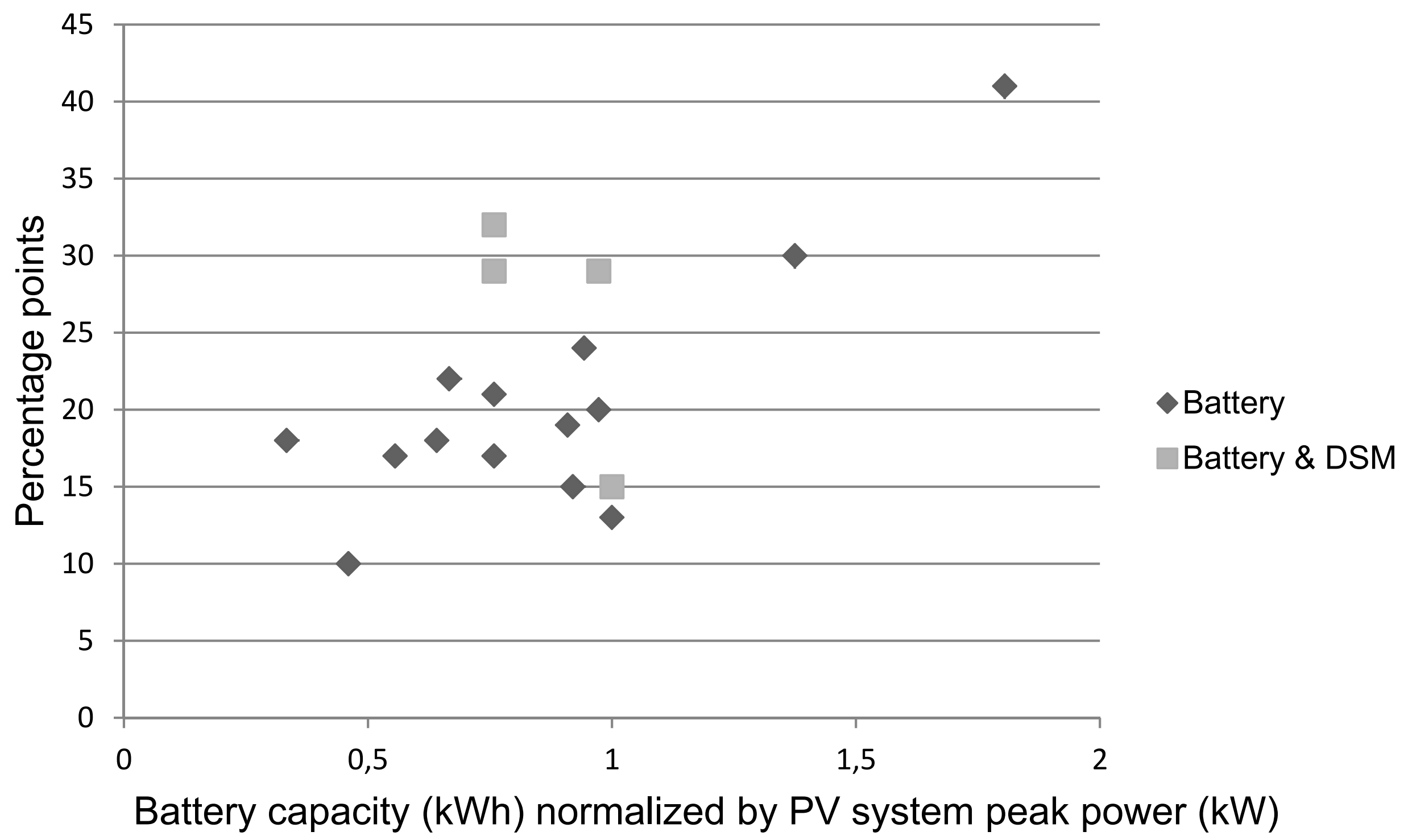




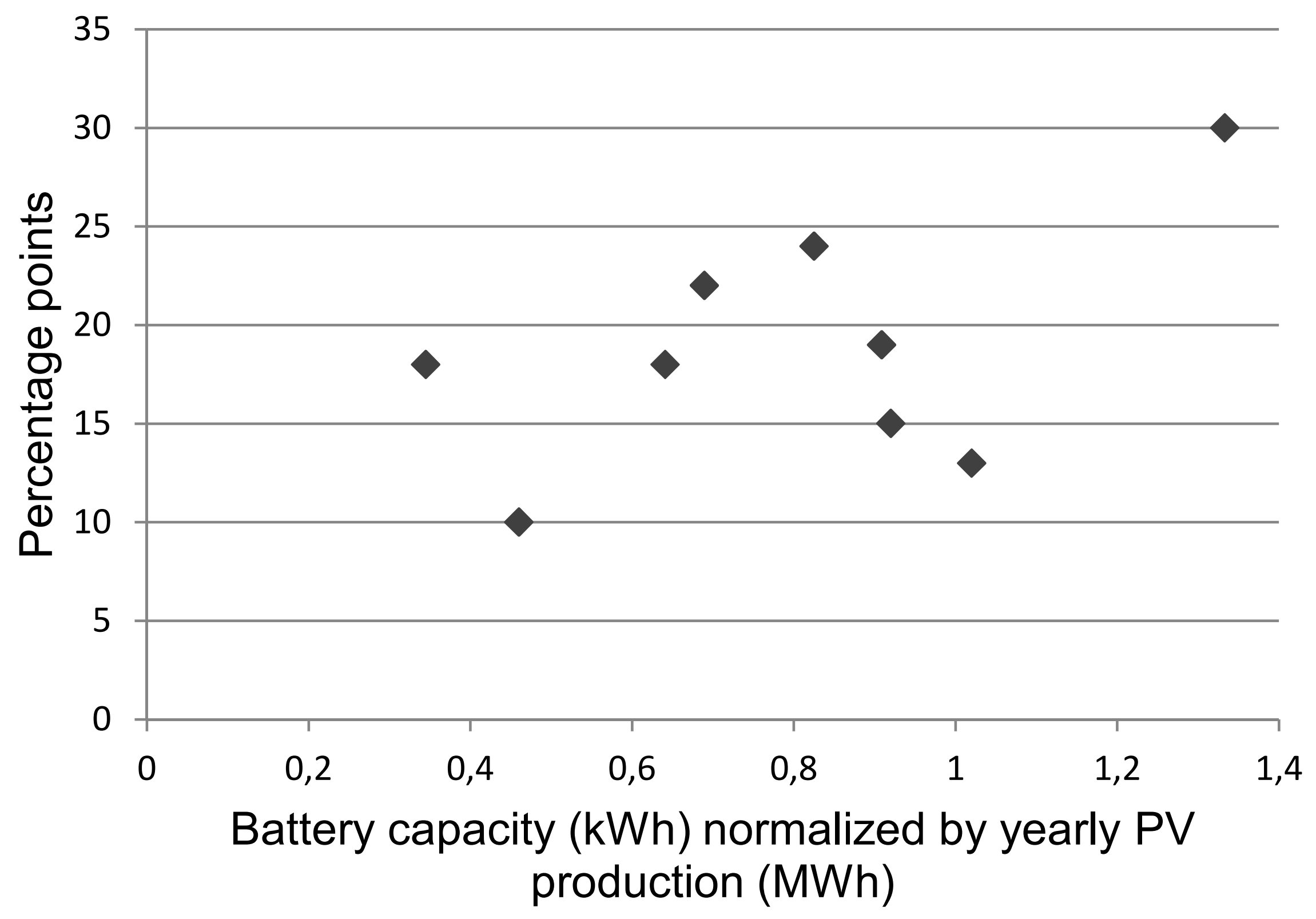




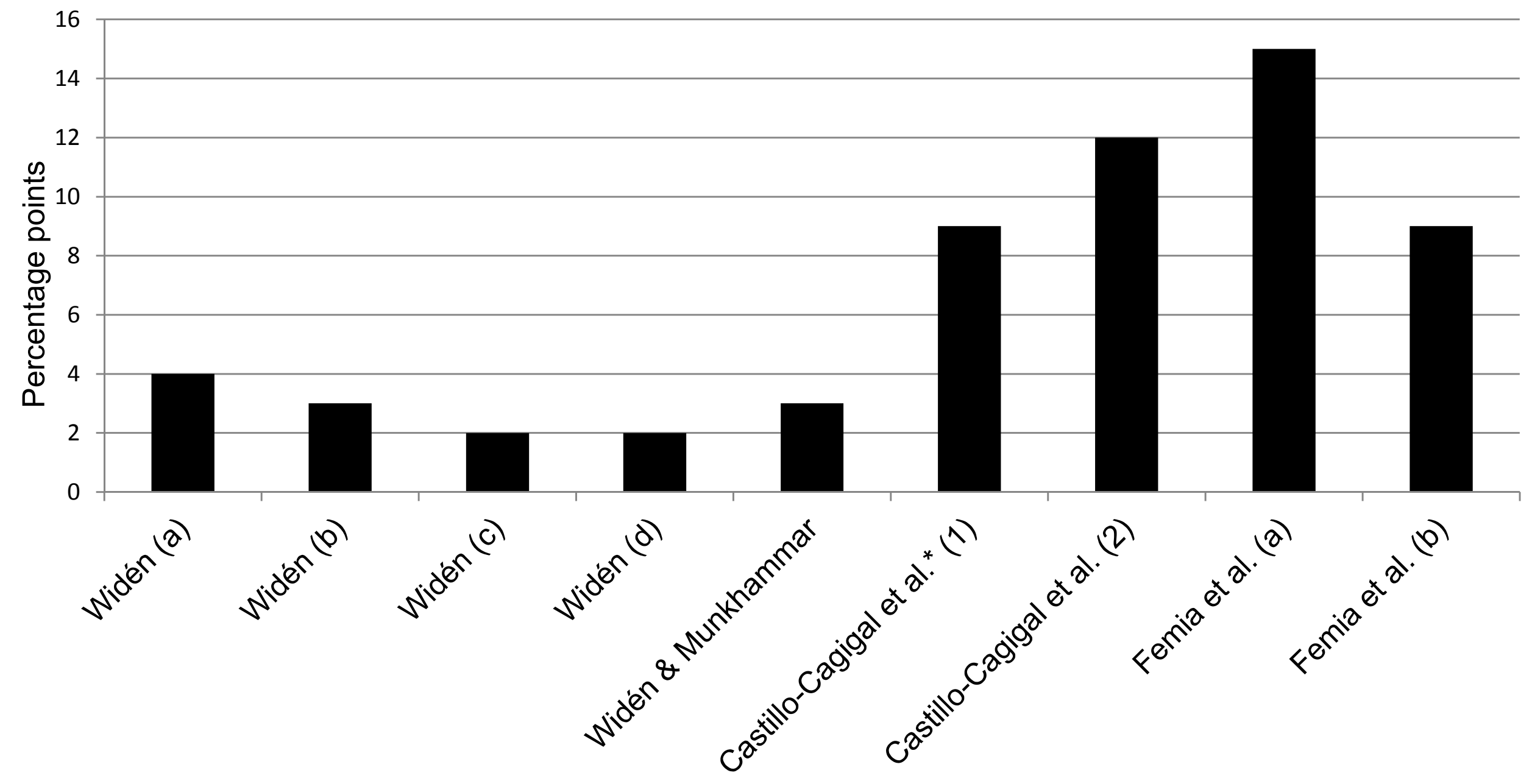



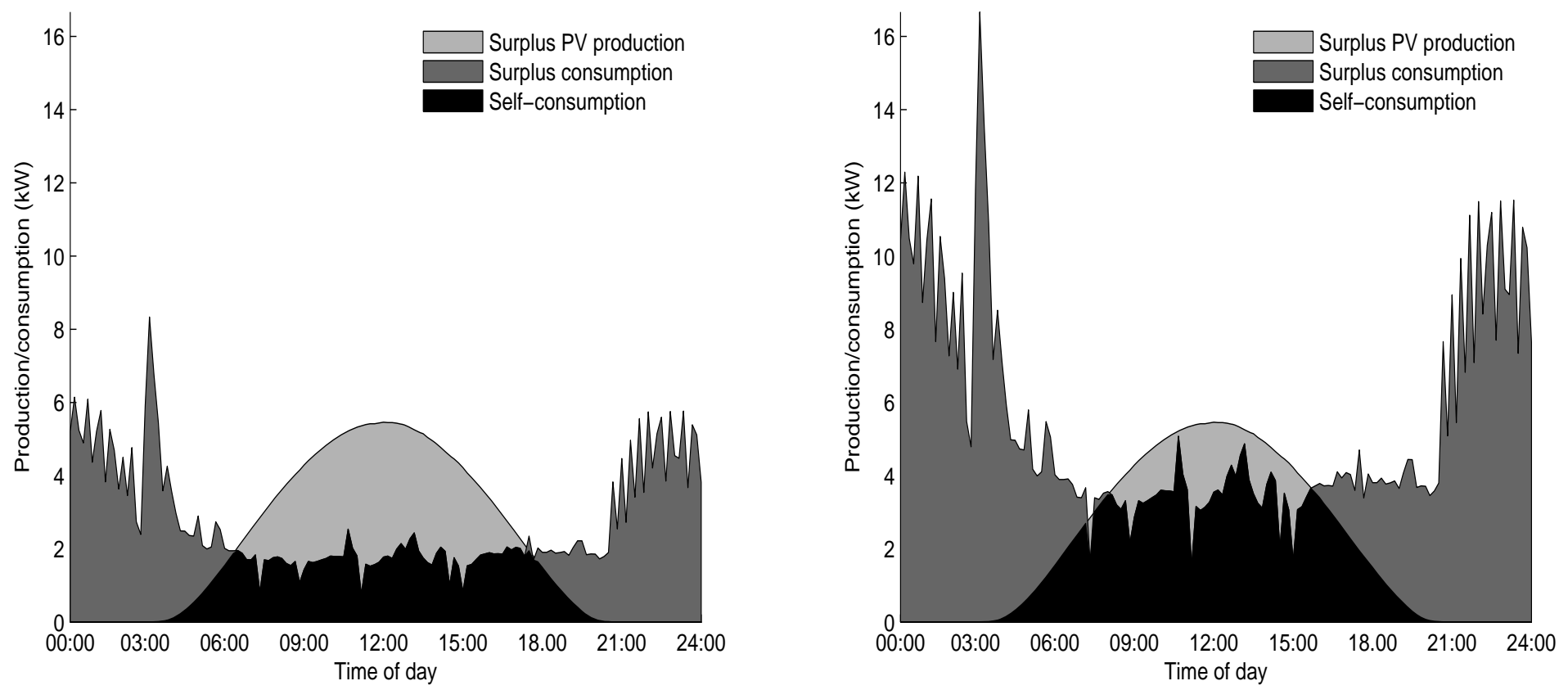

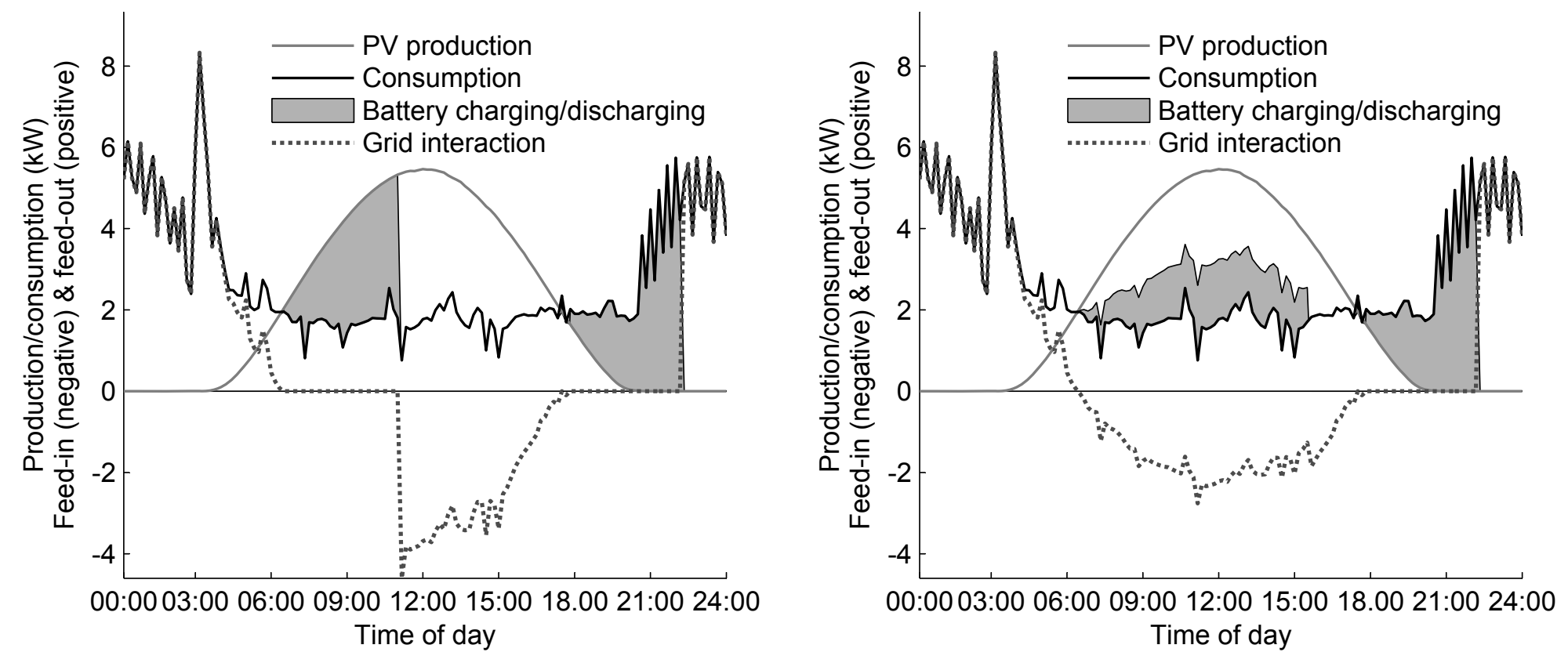